\title{
El baile: un lenguaje del cuerpo
}

Alejandro Ulloa Sanmiguel."

\section{RESUMO}

Es el resultado de una investigación donde se cruzan la lingüistica, la semiótica y la antropologia urbana para estudiar el baile como un lenguaje no verbal, una práctica social y un acontecimiento cultural, en los sectores donde es una forma de relación ( y no una moda) para las personas que lo disfrutan como una de sus actividades más importantes en la vida cotidiana

\section{ABSTRACT}

$I I$ is the result of an investigation where they cross the linguistic one, the semiotic and the urban anthropology to study the dance like a nonverbal language, a social practice and a cultural event, in the sectors where it is a form of relation (and not a fashion) for the people who enjoy it like one their more important activities in the daily life.

\footnotetext{
Alejandro Ulloa Sanmiguel, licenciado en literatura, mestrado en linguistica y español, mestrado en antropologia Unicamp, estudios de dotorado en comuncación y cultura UFRJ. Profesor e investigador en la escuela de comunicación social de la Universidad del Valle desde 1980 hasta la fecha, en las àreas de escritura, semiolinguistica, antropologia urbana, comunicación y educación. Ha investigado sobre culturas populares relacionadas con la música en la ciudad, imaginarios e identidades urbanas.
} 


\section{Para los bailadores \\ Que han hecho del baile \\ Un arte y una pasión. \\ Para los hombres y mujeres que se enamoraron bailando....}

El cuerpo sabe más del mundo que la conciencia.

\section{Introducción}

Durante la segunda mitad del siglo XX y sobretodo durante las últimas décadas, se han desarrollado en el ámbito académico una serie de estudios sobre la música popular contemporánea. Una amplia revisión bibliográfica nos indica que tanto en Estados Unidos como en Europa y en América Latina, la música popular se ha convertido en un objeto de análisis sociológico, asumido en el marco de los estudios culturales donde convergen enfoques y perspectivas de distintas disciplinas. Ya no sólo desde la musicología y la etnomusicología, sino desde la antropología , la semiótica y los estudios poético-literarios, hasta los análisis sobre los medios de comunicación y la industria cultural relacionados con la música. Esta eclosión de investigaciones ocurrida en diferentes países, corresponde sin duda, al desarrollo de la música misma, su evolución y

124 sus transformaciones en distintas partes del mundo; al desarrollo de la industria cultural (Industria discográfica, el video, el cine, la televisión y el espectáculo del concierto ); al auge y la importancia de la música popular en la vida cotidiana y a su papel en la configuración de nuevas identidades. Pero tiene también sus antecedentes en toda la investigación etnográfica realizada a lo largo del siglo XX sobre el folclor nacional, sobre las fiestas patronales, los carnavales y otros eventos donde la música y su baile son un acontecimiento central, uno de los motivos que evocan la celebración del mundo, por pueblos de distintas sociedades.

En Argentina, en el Brasil y en Cuba - para citar tres casos paradigmáticos - la música popular creada en los barrios populares de las grandes ciudades - puerto como Buenos Aires, Río de Janeiro y la Habana , en la segunda mitad del siglo XIX y desarrollada por la industria a partir del siglo XX, se convirtió después en símbolo nacional, en uno de los signos de identidad cultural más importante para sus respectivos pueblos.

Por estas razones, entre otras, se han estudiado los géneros musicales, estilos, compositores e intérpretes, asi como se han descrito extensamente carnavales, fiestas y danzas folclóricas en campos y ciudades. Pero poco se ha invetigado el baile de la música popular urbana, como un lenguaje específico, un lenguaje que aunque está indisolublemente ligado a la melodía y el ritmo, puede ser estudiado en su 
relativa autonomia, desde una perspectiva semiótica, como un lenguaje del cuerpo. Ese es el propósito de este ensayo.

\section{La descripcion del objeto - el punto de vista semiótico}

El estudio de la música popular debe considerar los modos de bailar como prácticas sociales a través de las cuales también se comunica y se significa el mundo. La interacción de los cuerpos y el movimiento en el espacio ponen en escena códigos, sensibilidades y gestos que conforman un lenguaje con el cual el cuerpo también habla. Y ello es válido tanto para la danza folclórica, moderna, o el ballet clásico, como para el baile de la música popular en cualquiera de sus géneros y en todas las culturas.

En este texto se propone un punto de vista semiótico para referirse al baile de la música popular, como un lenguaje no verbal a través del cual se expresan valores de la estructura social, en las relaciones de los bailadores entre sí y de ellos con los ritmos, en los diferentes contextos de la fiesta donde el baile tiene lugar como acontecimiento social y cultural. Para intentar una descripción de ese lenguaje, se ha contado con diversas fuentes de información oral, entrevistas, visitas y un amplio trabajo de campo basado en la experiencia personal y la observación participante de quien escribe, acompañada de grabaciones en video realizadas en distintas ciudades donde se registraron diferentes modos de bailar la música popular contemporánea : el tango, el bolero, la salsa, el rap, el rock, el merengue, el trance, el pogo. Aunque serán la salsa y el danzón bailado en México, el objeto particular de esa descripción y sobre la que se hará énfasis en el ensayo. (')

Este material audiovisual servirá como referencia para un análisis que comprende dos ejes complementarios, aunque tratados separadamente : primero, una descripción sincrónica del baile de la salsa y del danzón como un lenguaje del cuerpo. ¿Es posible lograr una descripción exhaustiva de los códigos que integran el lenguaje del baile y al baile como un lenguaje? Cuál es la naturaleza de esos códigos, cuáles son sus unidades y cómo se articulan en él? Si el baile es un lenguaje no verbal, qué lo diferencia y lo aproxima al lenguaje natural?. Estas preguntas subyacen a la exposición de este ensayo que hace parte de un trabajo más amplio y que aqui explorará, a través de un procedimiento comparativo, las diferencias y las implicaciones simbólicas de otros modos de bailar - otros lenguajes - como el bolero, el rock, la lambada, el trance (o tecno ) y el pogo que es el baile del punk.

Segundo, una descripción diacrónica, es decir histórica y etnográfica del baile de la salsa en Cali, la ciudad objeto primordial de mis observaciones y de mi reflexión sobre la música y la cultura popular urbana. Esta segunda descripción, que se desarrollará en otro artículo, apunta hacia una historia de ese cuerpo que baila, el cuerpo bailador, para el que el baile es una forma vital 
de comunicación, un escenario primordial de socialización. ¿ Cómo se ha moldeado ese cuerpo? Cómo ha sido modelado a lo largo de medio siglo de existencia en la ciudad de Cali? Que mediaciones tecnológicas y culturales han intervenido en la modelación del cuerpo bailador? ¿En qué espacios y por medio de cuáles prácticas sociales el baile se convirtió en una fuerte tradición cultural urbana para determinados estratos sociales? ¿Qué implicaciones simbólicas tiene en la historia de una ciudad como Cali, el baile en general y el baile de la música de vieja guardia cubana y la salsa en particular, para los sectores populares - y entre ellos la población negra - , que son los que más bailan?

\section{El Baile: objeto y acontecimento}

Antes que un objeto, el baile es un acontecimiento. Un acontecimiento móvil, fluído en el espacio y efimero en el tiempo. Dura lo que dura una canción...A diferencia de la música que está construída sobre el tiempo, el baile, al igual que la danza, se realiza simultáneamente en el tiempo y en el espacio. Es, por eso mismo, dificil de aprehender racionalmente y más dificil aún es representarlos gráficamente. Ann Hutchinson ha señalado con lucidez las limitaciones de todos los intentos de notación y registro de la danza, desde el siglo XVI,cuando apareció el primer proyecto de notación gráfica, “" Orchesographie", de Thoinot Arbeau, (1588) hasta las actualizaciones del 126 sistema Von Laban, o "danza escrita", (1928). Esta particular forma de escritura no ha logrado resolver "los tres problemas fundamentales de la notación de la danza - según Hutchinson - : registrar adecuadamente movimientos complicados; hacerlo en forma económica y legible; y mantenerse acorde con las continuas innovaciones del movimiento". $\left({ }^{2}\right)$

A pesar de los logros del sistema Von Laban, cada vez más difundido para representarla por escrito, la danza no cuenta ( $y$ el baile tampoco) con una especie de partitura dancística que muestre la ejecución de todos los movimientos, sus matices, diseños, y la complejidad de las interacciones kinésicas y proxémicas que les son propias. Se ha llegado a un registro analógico de los pasos, a representar ciertas figuras y coreografias pero siempre de manera aproximada y convencional. Alberto Dallal, en su estudio sobre "El dancing en México", atribuye esa dificultad de notación al carácter efímero del acontecimiento, y reseña la imposibilidad, de registrar (...)" claridad, fluidez, inclusión de actitudes e intenciones, registrabilidad universalizadora, reproducción fácil e inmediata (...)". Y luego anota : "Elementos como la respiración, el impulso, la intensidad, la retroalimentación formal y el apoyo musculares,etc. no pueden quedar registrados, hasta el momento, en ningún tipo de "partitura" dancística..."(3). Por eso, la grabación audiovisual como reproducción en imágenes del acontecimiento in situ, es actualmente la mejor forma de registro en tanto fuente de información para el 
análisis y como herramienta del trabajo de campo, útil para la descripción etnográfica del baile, en tiempo y espacio real.

\section{El baile, la danza y el ballet}

Algunos estudiosos han partido de una diferenciación radical entre la danza y el baile, atribuyéndole a aquella un carácter artístico que el baile no tiene. Asi por ejemplo, Adolfo Salazar, desde una clara concepción etnocentrista desplegada en su libro "La danza y el ballet," enfatiza desde el comienzo que se ocupará "sólamente de la danza de arte, que es la que ha de intervenir en el ballet...," y excluye las danzas étnicas y populares que caen fuera de su propósito." $\left({ }^{4}\right)$. Alberto Dallal, a su vez, parece pasar por alto esa distinción entre la danza y el baile; y cuando la reconoce, lo hace en función de dos criterios dispersos : de un lado, la conciencia estética ligada a una intencionalidad de trascender por parte del sujeto que quiere hacer arte con la danza y no sólamente bailar; lo que en otras palabras equivale a decir que 'sólamente hay arte en la danza y no en el baile.. De otro, la diferencia se homologa a la distinción entre arte y artesanía, que Dallal traslada mecánicamente a la danza y el baile, oponiendo la rigidez, la disciplina y la técnica de la danza (clásica, moderna y contemporánea ), a la flexibilidad y la espontaneidad del baile, que no respondería a un código rígido como sí ocurre con la danza y el ballet. ( 55 . A. Dallal. Op.cit págs. 25 a 35)

Como veremos luego, la diferenciación entre la danza (el ballet) y el baile es pertinente y es necesaria para nuestro análisis, pero bajo otros criterios. Ni el prejuicio etnocentrista, ni las oposiciónes arte-artesania, o código-no código, son suficientes, ni son tampoco los criterios más importantes para distinguir la danza del baile de la música popular contemporánea. A nuestro juicio, las diferencias son históricas y son estructurales. Es decir, tanto por su origen popular-cortesano (una oposición que consideramos aqui ), como por su organización y regulación interna, la danza "arte" es diferente del baile de la música popular. Es sabido que la danza y el ballet tienen un claro origen aristócrata pues se cultivan y desarrollan en las cortes europeas, desde el renacimiento hasta el siglo XIX. Tienen un canon que las rige con sus propias reglas plenamente codificadas. Ese canon y esas reglas son un producto de la ilustración francesa, consagrada definitivamente en las "Cartas sobre la danza y sobre los ballets" de J. Noverre, publicadas en el siglo XVIII ( $\left.{ }^{6}\right)$.

Habria que considerar que más allá de las diferencias formales, técnicas, musicales y de otra indole que pudieran haber entre la danza, el ballet y el baile, hay también una ideologia que las sustenta. En otras palabras, la consideración de la danza y el ballet como arte y del baile como algo que no lo es, pasa también por una dimensión ideológica y política que 
subyace al proceso histórico social y que desde el renacimiento introdujo esa distinción y la ha ido consolidando hasta nuestros días, como un prejuicio social y cultural.

\section{La Mimesis: analogía y representación}

En el conjunto de las artes, la música y la poesía se relacionan con el tiempo, mientras la escultura y la pintura, al igual que las artes gráficas existen en el espacio. Como ya se dijo antes, el baile se relaciona simultáneamente con el tiempo y con el espacio, y aunque no se le reconoce como un componente de las artes escénicas, tiene algunos aspectos en común con el ballet y con la danza, que sí gozan de un estatus artístico y de un reconocimiento como objetos culturales. Ciertos movimientos del cuerpo, pasos y algunas coreografias, pueden encontrarse en todos ellos. Sin embargo la danza, generalmente de carácter mimético, ha sido asociada a procedimientos rituales de la religión y de la magia, en las sociedades ágrafas, bien sea para la invocación del espíritu de los ancestros, para celebrar la caza y las cosechas, o bien para someter imaginariamente las fuerzas naturales, ritualizar la guerra, representar la vida y la muerte, simbolizar las divinidades, o simular acciones relacionadas con ellas ${ }^{7}$.Así mismo, en las sociedades agrarias, la danza como parte del folklor campesino, es ante todo representación imitativa, integrada al sonido instrumental y la palabra cantada. Es decir, sus movimientos, al igual que en el ballet, (donde se dramatiza musicalmente una historia) se realizan con diferentes grados de semejanza o des-semejanza, como representación de algo externo a ellos.

La mimesis, es decir la imitación, está en el origen de la danza así como está en el origen del lenguaje verbal y de todas las artes en general ${ }^{8 .}$

A nivel filogenético, el ser humano adquiere la lengua materna y aprende a hablarla a medida que imita y reproduce las palabras del entorno sociofamiliar. (A propósito, este es un excelente método para aprender una segunda lengua en su medio nativo.)

La mimesis, analizada por Aristóteles en su Poética, es una de las formas fundamentales de lo simbólico en la especie humana; ella expresa la capacidad de hombres y mujeres para simbolizar y representar el mundo. (Refiriéndose al origen del hombre, la frase bíblica del Génesis sintetiza magistralmente el principio simbólico de la imitación y la analogía cuando dice que "Dios creó al hombre a su imagen y semejanza".)

Ahora bien, la mimesis ha sido interpretada básicamente de dos maneras : como imitación, semejanza y analogía, o bien en el sentido de ocultamiento y disfraz, es decir como simulación de lo que no se es. Lo ilustran los ya conocidos comportamientos de plantas y animales que se mimetizan en su entorno para cazar a sus presas, o para protegerse de otros predadores. En otro contexto, los actores armados en guerra se mimetizan 
con el uniforme militar oficial, como parte de sus tácticas para enfrentar al enemigo?.

La representación mimética, en sus distintos significados y gradaciones, como característica fundamental de la danza, es compartida con el ballet y el teatro en el conjunto de las artes escénicas. Así por ejemplo, desde las tiranas andaluzas en la península ibérica del siglo XVIII hasta los bailes actuales del bambuco, el joropo y el currulao en Colombia, la danza simula los gestos de seducción, coqueteo y enamoramiento, incluso con roles definidos en la escena. En la representación bailable del cortejo, el varón juega a perseguir a la mujer mientras ella juega a la huida, con acercamientos y distanciamientos alternos, ademanes, sonrisas, simulación de besos y caricias.

Si la danza es simulación - imitación de un referente externo a ella, el ballet es representación de una historia que se cuenta, se canta y se danza al mismo tiempo. Esa es su finalidad y su propósito primordial. En el siglo XVIII se definió su canon estético cuando el director y coreógrafo francés Jorge Noverre estudió las bases anatómicas de la danza y el ballet, y fundamentó sus técnicas como expresión teatral. En sus "Cartas", escritas hacia 1770, Noverre define la danza como "Imitación embellecida de la naturaleza"... Su primera carta comienza con esta afirmación : "La poesía, la pintura y la danza no son , o no deben ser otra cosa que una copia fiel de la bella naturaleza. Por la veracidad de esta imitación han pasado a la posteridad las obras de los Racine, de los Rafael..." Más adelante insiste en ello al preguntar si "Se ignora acaso que la danza es un arte de imitación "? Y con respecto al ballet dirá que "El ballet bien compuesto es una pintura viviente de las pasiones, costumbres, usos, ceremonias y vestimenta de todos los pueblos de la tierra (...) del mismo modo que la pintura exige una perfección no muy fácil de conseguir, pues el ballet está subordinado a la fiel imitación de la naturaleza..."'”

\section{El Baile: la metafora del tiempo}

Esta dimensión metafórica o analógica de la danza y el ballet, no existe de manera tan radical en el baile de la música popular. Aunque en determinados casos encontramos una forma de simulación - curiosamente la más expresiva y universal - como es la analogía con la seducción erótica que percibimos en algunos pasos del tango; o la simulación del acto sexual como sucede de manera más explícita en el baile de la lambada brasilera y del hip hop, el rap o el reggae jamaiquino. Ahora bien, esa representación del coito está presente en muchas danzas folclóricas de distintas culturas (En "el vacunao" del guaguancó en la rumba cubana; en el mapalé colombiano; en el lundú, y la lambada brasilera)". Y al igual que otros gestos, ademanes y figuras de las danzas primitivas, está presente en el baile de la música popular contemporánea, con el cual establece una línea de continuidades irregulares. 
Pero en términos generales, el baile - y en particular el baile de la música salsa que se describirá más adelante - no representa un objeto externo a él, ni una acción cualquiera ; ni siquiera representa el acto de caminar que parecería lo más obvio ; su finalidad no es mágica ni religiosa, ni su propósito está en imitar un mundo real o imaginario. Su razón de ser radica en el goce propiciado por la sincronización entre la pareja y por la sincronización de ésta y cada uno de los integrantes con la música y el ritmo. Tal vez, en rigor, la única representación que pueda atribuírsele al baile, es la representación del tiempo rítmico, del tiempo musical. El baile es, probablemente, su única metáfora posible, la perfecta metáfora del tiempo... Es lo que se puede constatar en un modo específico de bailar la salsa y en el modo singular como bailan el danzón en México, para citar dos ejemplos significativos, caracterizados por la presencia de la síncopa, esa alteración rítmica que encontramos en otros géneros con ancestro africano como el jazz y el samba brasilero. La síncopa entendida como el golpe que falta, es decir la ausencia en el compás, de la marcación de un tiempo débil que repercute en otro más fuerte. Como ha dicho Muniz Sodré: "La síncopa es una alteración rítmica que consiste en la prolongación del sonido de un tiempo débil en un tiempo fuerte. Esta alteración no es sólamente africana, pues los europeos también la conocían " (...) "La síncopa invita al oyente (al bailador ) a llenar el tiempo vacío con la marcación corporal - palmas, meneos, balanceos, baile. Es el cuerpo que también falta - en la llamada de la síncopa. Su fuerza magnética, compulsiva incluso, viene del impulso (provocado por el vacío rítmico ) para completar la ausencia del tiempo con la dinámica del movimiento en el espacio"' 2 . Aunque se trate de un tiempo fragmentado en las pulsaciones del compás, el baile como un lenguaje no verbal marca con los pasos y los gestos precisos el tiempo y el ritmo musical.

Con respecto a los pasos, movimientos y figuras, en la danza predominan los movimientos del danzarín individual y las coreografias colectivas, sobre el baile de la pareja enlazada. Para nuestra cultura mestiza, ambos tienen sus antecedentes en la edad media, en las fiestas campesinas, en las fiestas de las cosechas, en la danza "baja" con los pies pegados al suelo y en los branles, (balanceos ) o bailes cortesanos que se realizaban en los castillos franceses del siglo XVI. (Salazar : infra)

Ahora bien; ¿Es la pareja enlazada un formato universal ? Ha existido la pareja enlazada desde los orígenes de la danza primitiva, o es el resultado de una transformación histórica dada en el contexto de la modernidad occidental ? Si fuera así, en qué condiciones específicas se transformó el gesto danzario colectivo en baile de pareja enlazada independiente? ¿ Cómo se transformó la danza que se hacía en hileras de individuos frente a frente o en cuadrillas ( como la contradanza francesa o el country-dance inglés) en baile de pareja enlazada ? Estas preguntas orientarán nuestra reflexión en las líneas que siguen. 
Algunos autores han abordado el tema en otros términos. Olavo Alén por ejemplo, lo menciona de paso ( pero no lo explica ) cuando se refiere a la danza y el origen del danzón en Cuba. Dice Alén: "La contradanza cubana fue siempre un baile de figuras y mantenía estructuras muy parecidas a otros bailes de figuras traídos por lo europeos, tales como los lanceros y las cuadrillas. La danza dio paso a un elemento coreográfico proveniente de Europa que no habia aparecido entre los grupos africanos que poblaron el pais : el baile de parejas enlazadas...los bailes de pareja alcanzaron una gran popularidad durante el siglo XIX. Su incremento paulatino en la preferencia del público que asistía a los bailes, hizo desaparecer lentamente a los bailes de figuras"13.

Ramos Tinhorão por su parte, citando fuentes escritas del siglo XIX, señala la llegada al Brasil del baile de la polca, llevado por primera vez a Río de Janeiro en 1845, ("en el teatro San Pedro") por una compañía de teatro francesa. La danza permeó las élites cariocas y se regó por las clases medias, con todo el prestigio de su procedencia francesa. Según Tinhorao "Ese tipo revolucionario de danza de pareja enlazada, capaz de permitir la aproximación de los cuerpos de los bailarines... era la polca. "Y más adelante agrega: "La polca reforzaba la intimidad que ya era proporcionada por el vals, el cual era ya un baile de pareja enlazada. Pero la polca traía una nueva contribución, en la substitución de los giros alados en $3 / 4$, por el vuelo en la punta de los pies. Era el movimiento de avance del pie izquierdo, estancándose oblicuamente hacia la izquierda ; luego, el pie derecho avanzando hasta él , que de inmediato se desliza hacia adelante, permitiendo al bailarín de polca levantar el pie derecho, antes de recomenzar la serie de tres pasos nuevamente con el pie |izquierdo" I4. Con el tiempo la polca permeó las élites cariocas y se regó por las clases medias urbanas con todo el prestigio de su procedencia francesa. Ahora bien, cuando la polca llegó, ya existia en el Brasil la danza del lundú, traída del Africa, como un baile popularizado desde comienzos del mismo siglo, que aunque no era de pareja enlazada, sí acercaba los cuerpos mediante movimientos lascivos, giros pélvicos, requiebros y meneos eróticos, que provocaban el escándalo y la censura de la moral dominante.

Esta danza africana se caracterizaba por la "umbigada", o semba ( que en dialecto de Angola significa ombligo, y de cuya palabra se deriva samba, para designar este género de la música brasilera). La "umbigada" (que podría traducirse como ombligada) no es otra cosa que el contacto de ombligo con ombligo entre el hombre y la mujer que se juntan en el baile, con movimientos pélvicos, contorsiones y meneos frente a frente.

Poco después, la polca empezó a ser bailada no tanto como la habian mostrado los europeos, sino con los nuevos movimientos incorporados del lundú y la umbigada, transformando su coreografia. La intensidad del fenómeno fue tal que dio lugar no sólo a una forma particular de interpretarla y bailarla, sino también a un nuevo género bailable : la polca lundú y el maxixe, que 
apareció hacia 1870 ( paralelamente con la milonga y el tango en el Río de la Plata ) como una forma inédita de bailar la pareja enlazada, desarrollada por sectores populares urbanos, negros y mulatos en el barrio "A Cidade Nova" de Río de Janeiro. El maxixe se prolongó durante unos cincuenta años, constituyéndose en el antecedente inmediato del samba brasilero. (Tinhorao: infra).

Las anteriores referencias nos permiten avanzar en la hipótesis de que frente a la diversidad de expresiones danzarias (en círculos, hileras, grupos, cuadrillas ) el baile de la pareja enlazada que conocemos hoy, es una relación fundamentalmente desarrollada por las culturas populares urbanas de América Latina en el paso del siglo XIX al siglo XX, como forma decantada del cruce entre danzas oriundas de Europa, con danzas de origen africano principalmente, que se encontraron y se transformaron en el nuevo mundo. Así lo ilustrarían el caso del tango en El Río de la Plata, del Maxixe y el Samba en Río de Janeiro y el danzón en Matanzas y la Habana en Cuba ; todos ellos bailes de pareja enlazada surgidos en América Latina y el Caribe durante la segunda mitad del siglo XIX.

Por eso el baile - y específicamente el baile de la pareja enlazada puede analizarse también en su especificidad como un fenómeno relativamente autónomo, independientemente de sus conexiones con la danza y el ballet, a pesar de su no reconocimiento como objeto de estudio para la academia. Porque mientras el ballet es, sin duda, un objeto de estudio especializado y

132 una práctica cultural socialmente prestigiosa con tradición histórica y un alto valor simbólico, el baile de la música popular carece de estas connotaciones. Y aunque cercano a la danza popular y folclórica (estudiada a su vez por la etnomusicología ), el baile parece no tener un discurso ni un método definidos para asumirlo como objeto de conocimiento, no obstante su popularización internacional y a pesar del carácter masivo de su realización como componente de un nuevo tipo de folclor : un folclor urbano y moderno, configurado por la interacción entre la industria cultural y los públicos receptores, a lo largo del siglo XX.

Pero las diferencias del baile con la danza y el ballet no se reducen a las formas de imitación o analogía, ni a los grados de semejanza o arbitrariedad con que representan su "objeto". Porque mientras el baile se sustenta fisicamente en la ley de la gravedad, es decir con los pies en el piso, siguiendo las posiciones naturales del cuerpo con movimientos "normales", el ballet se fundamenta en una lógica contraria mediante la cual los movimientos danzarios desafian la ley de la gravedad y el equilibrio, en busca de la levitación, en procura de la dinámica suspensión de los cuerpos en el aire, que producen una especial plasticidad. Ello exige no sólo un esfuerzo fisico mayor sino el aprendizaje juicioso de una técnica refinada para lograr expresiones y gestos corporales extracotidianos. En cierto modo, la danza clásica del ballet se desarrolla con movimientos fuera de lo común, ( teniendo como uno de sus principios los pies y los muslos hacia fuera ), tal 
como lo prescribiera Noverre en sus "Cartas": "Nada es más necesario que la vuelta del muslo hacia fuera para bailar bien". Así mismo, las cinco posiciones básicas de los pies en el suelo definidas desde el siglo XVII por la academia de la danza ${ }^{15}$. A propósito: No hay aquí una contradicción de su postulado mimético? Acaso, no es lo más antinatural poner los pies y los muslos hacia fuera? En qué radica entonces la imitación de la naturaleza?

Tal vez, esta diferencia fundamental ha determinado que la danza y el ballet se consideren como lenguajes artísticos propiamente dichos, diferentes a las danzas tradicionales que se asumen como folclor, mientras el baile de la música popular contemporánea no se considera ni lo uno ni lo otro. En rigor, siguiendo a Noverre, deberíamos concluir en que el carácter estético de la danza no radica en la imitación y la semejanza con lo natural, sino en todo lo contrario, es decir en el máximo de arbitrariedad, esto es, en la des-semejanza y la discontinuidad con el orden natural ${ }^{16}$.

Pero, volviendo al baile, si este no es tampoco imitación total, cuál es entonces su "lugar" en el campo estético de la sociedad contemporánea? Acaso tiene cabida en el ámbito de las artes escénicas como se definen actualmente? Parece que no ${ }^{17}$. Como veremos luego, es posible, a partir de la semiótica, describir el baile (no prescribirlo) como un lenguaje diferente y autónomo que si bien no goza de un estatus artístico ni académico, sí se reviste de prestigio y alcanza altos grados de simbolización allí donde se convierte en una forma de socialización primordial en la vida cotidiana, lo que no ocurre con la danza ni el ballet como prácticas artisticas altamente estilizadas... y elitizadas.

\section{Música popular y folclor urbano en América Latina}

El folclor urbano y moderno que se plantea aqui, corresponde en América Latina al caudal de géneros, bailes, canciones y cancioneros musicales producidos y desarrollados en las ciudades más importantes, durante el proceso de modernización y constitución de los estados nacionales de este continente. Un folclor que si bien tuvo estrechos vínculos con el campo y las poblaciones rurales, lo fundamental de su producción y consumo tuvo lugar en las ciudades donde se concentró la mediación industrial y tecnológica de la radio, el disco y el cine.

Este folclor urbano con raices africanas tiene un rasgo común en la síncopa, su caracteristica fundamental. Consideramos también que este folclor urbano comprende los formatos instrumentales, la organologia, las canciones, los géneros musicales en sus diferentes estilos, y sus correspondientes formas de bailar, creados unos y otros por los sectores populares y por comunidades marginales, en barrios y ciudades latinoamericanas y caribeñas. Así lo demuestra, en el paso del siglo XIX al siglo XX, la historia individual de varios ritmos como la milonga y el tango, nacidos en suburbios de Buenos Aires (en barrios como La Boca, El Retiro, 
Corrales Viejos, SanTelmo ) y en Montevideo, en la otra orilla del río de la Plata ${ }^{18}$. $O$, en el caso del maxixe, el samba y el pagode, germinados en los barrios bajos de Río de Janeiro (en la Lapa y la Plaza XI) antes de consolidarse en los morros y favelas de "la ciudad maravillosa". Igualmente lo ilustra la historia del son montuno desarrollado en barrios de Santiago de Cuba ( en el Tívoli), antes de llegar a la Habana, donde sería enriquecido $\mathrm{y}$ transformado con nuevas sonoridades. O el caso de la rumba cubana y el guaguancó, ritmos gestados en Belén, Pueblo Nuevo y Jesús María, barrios negros de la Habana, desde donde salieron para contribuir a la música popular de América Latina y a la cultura mundial del siglo XX.

La música popular, constitutiva del folclor urbano latinoamericano, es el resultado del cruce, bajo determinadas condiciones históricas, entre tradiciones musicales europeas como las tiranas andaluzas, la contradanza francesa, la modinha portuguesa,el chotis, la polka y el minué, que se fusionaron creativamente en el nuevo mundo, con tradiciones musicales de origen africano y de carácter ritual, como los cultos de las religiones Yoruba, Arará, Bantú, Lucumí o Carabalí, allí donde florecieron la plantación y la hacienda esclavista, bajo el yugo del amo colonizador y el trabajo del africano esclavizado. De este encuentro desigual propiciado por la modernidad y la expansión del capitalismo internacional durante los últimos siglos, iniciado en la plantación y continuado en el barrio citadino, surgió una nueva corriente sonora que llegó a convertirse en materia prima esencial para el

134 desarrollo de la industria cultural a lo largo del siglo XX, gracias a tres maravillas tecnológicas : la radio, el disco y el cine, que lo difundieron por el mundo Dicha corriente se materializó en lo que aquí propongo llamar un cancionero popular - comercial del nuevo mundo, anclado en el folclor nacional tradicional de los países americanos que constituian los cancioneros coloniales, entendido el Cancionero como un repertorio de géneros musicales - no de canciones - que coexisten públicamente en un momento dado de la historia, para una población determinada ${ }^{19}$.

$\mathrm{La}$ industria cultural se apropió así de los repertorios musicales folclóricos y populares, para desarrollar un mercado que con el tiempo, al promediar el siglo, llegó a proyectar identidades locales, etnicidades y expresiones de culturas subalternas de América Latina, como lo demuestra el hecho de que los géneros populares urbanos, nacidos en los barrios mencionados, pasaron a ser representativos de todo un país y símbolos de la identidad nacional. El tango para la argentina, el samba para el Brasil, el son y la rumba para Cuba.

Ahora bien, este cancionero popular comercial como conjunto y repertorio de géneros musicales que aquí denominamos afrolatinoamericaribeño,(o afrolatinoamericaribebrasileño, si incluimos los géneros del Brasil), comprende el folclor nacido en las ciudades al ritmo de los procesos de industrialización y urbanización gestados en la transición 
del siglo $\mathrm{XIX}$ al siglo $\mathrm{XX}^{20}$. En gran medida dicho folclor tenía un pasado religioso, pero luego, profanado en el barrio y usurpado por la industria se transformó en su forma y su función. Con las nuevas tecnologías (el cine, el disco y la radio) se lanzará al continente todo, e incluso a la conquista del viejo mundo. La explotación comercial por parte de la industria cultural y el mercado, harán que el folclor urbano trascienda los límites del solar, en el barrio marginal, y sea escuchado en otras latitudes. Su difusión masiva y generalizada creará una memoria musical que hoy sobrevive a través de varias generaciones. Todos los ritmos del nuevo cancionero popular comercial conviven en el continente con géneros de origen rural, y con música de otros paises como Estados Unidos, hacia la misma época : entre 1930 y $1950 . \mathrm{El}$ tango, la milonga, el corrido, la ranchera, el jazz, el foxtrot, el charleston, la rumba, la guaracha, la conga, el son, el danzón, el guaguancó, el bolero, el bambuco, la cumbia, el merengue, el pasodoble y después (en la década del 50) el mambo, el chachachá y el rock and roll. Poco a poco los géneros irán decantando su propio público y en la recepción múltiple darán forma a esa memoria musical diferenciada que hoy en dia tiene toda clase de adeptos entre los diversos grupos de melómanos.. En un primer momento, la radio, el disco y el cine se encargarán de difundirlos multiplicando su audiencia, antes de que la televisión y el video establecieran su hegemonía audiovisual en la sociedad contemporánea, durante la segunda mitad y sobretodo al fin del siglo XX.

\section{El baile popular: unsaber y un placer}

Considerada en el contexto de ese folclor urbano, la música popular de América Latina fue desde sus comienzos una música hecha para bailar, por las comunidades que la produjeron. Desde entonces, los géneros y sus bailes han conformado una pareja indisoluble que se prolonga con la aparición de nuevos ritmos urbanos marginales como la salsa o el reggae que surgieron también con su propia forma de bailar, en otros guetos urbanos entre 19501960 y después se difundieron por el mundo ${ }^{21}$. Si en la audición de la radio y el disco se educó el oido, en el baile se educó el cuerpo. Un cuerpo relajado para el goce, un cuerpo que se exhibe en vez de doblegarse, un cuerpo que tiene en el corazón el origen del ritmo vital y vuelve a él hecho melodía. Un cuerpo adiestrado en el movimiento de los pies, de la cintura, de los brazos que la aprietan, marcando el paso, siguiendo el compás. Cuerpo que va y viene llevado por el ritmo, jugando con el tiempo. Bailar, es tal vez, la forma de comunicación no verbal por excelencia. Bien sea en la pista de una discoteca, al aire libre o en la sala familiar, el acontecimiento del baile permite otras formas de expresión entre los seres que bailan, independientemente del lenguaje verbal. A través de él los bailadores se comunican y pueden 
identificarse. No es necesario que las personas hablen el mismo idioma, para que puedan reconocerse o intercambiar sensaciones, sentimientos, habilidades y saberes que se comparten en la danzante interacción de los cuerpos. Más aún, podría decirse que tanto a nivel de la subjetividad de los bailadores como de su expresión quinésica, hay contenidos que no pueden comunicarse con palabras. Se sabe, desde las teorías de Lotman y Umberto Eco, que el lenguaje verbal es "El SISTEMA MODELADOR PRIMARIO, del que los demás lenguajes son variaciones", lo cual significa que cualquier clase de experiencia humana o de contenido expresable mediante otros sistemas de significación, puede traducirse en términos verbales sin que sea posible lo contrario. Esto es lo que Umberto Eco denomina la "Efabilidad total del lenguaje", es decir, su capacidad para asimilar y subsumir en sus formas a otros sistemas de comunicación y otros lenguajes, traducibles al sistema verbal, mientras que el lenguaje verbal no se puede traducir a ellos. Pero también Umberto Eco ha reconocido - citando a Wittgenstein y a Emilio Garroni- las limitaciones de esta "efabilidad total" del lenguaje humano cuando dice que : "Existen muchos contenidos expresados por unidades complejas no verbales, que no pueden ser traducidos por unidades verbales, a no ser mediante aproximaciones imprecisas"'22. Este es concretamente el caso del baile.

El baile ilustra muy bien este enunciado cuando reconocemos en él y vivenciamos por su intermedio, experiencias en las que el lenguaje verbal es innecesario no sólo porque no participa de la interacción, sino porque lo que se comunica a nivel sinestésico y emotivo es prácticamente imposible de representar con palabras. Por eso, hablar del baile es hablar también de un lenguaje no verbal, socialmente construido para establecer otras formas de comunicación, para experimentar otros modos de sentir al otro y de hacernos sentir ante él.

Como bien lo ha señalado el mismo Eco: "Sin duda, el lenguaje verbal es el artificio semiótico más potente que el ser humano conoce; pero a pesar de ello, existen otros artificios capaces de abarcar dimensiones del sentido que la lengua hablada no siempre consigue tocar...y para llegar a ser más potente de lo que es debe valerse de la ayuda de otros sistemas semióticos. Es dificil concebir un universo en el que los seres humanos se comuniquen sin lenguaje verbal, limitándose a hacer gestos, mostrar objetos, emitir sonidos o bailar; pero igualmente difícil es concebir un universo en donde los seres humanos sólo emitan palabras (...) En un mundo servido sólo por las palabras, sería dificilísimo mencionar las cosas..." ${ }^{23}$.

Además de ser una fuente de placer y un excelente ejercicio benéfico para la salud, el baile de la música popular, y en particular de la salsa, es una práctica social de carácter lúdico que se realiza a partir de unos códigos configurados culturalmente, los cuales es necesario aprender para poder interactuar con los demás. Todo código, como sabemos, hace parte de una 
gramática, es decir, constituye un saber, una capacidad para actuar, para desempeñarnos comunicativamente en determinados contextos. Pero se trata de un saber práctico, un conocimiento más intuitivo que teórico, más sentido que pensado, un saber hacer que marca los diferentes movimientos del cuerpo en la ejecución del baile y que podemos llamar, la performatividad corporal. En el caso específico del baile, ese contexto corresponde al acontecimiento de la fiesta, o de la rumba, como llamamos en Colombia a cualquier actividad festiva que involucra música, licor y baile, ( a veces algo más) en tanto modo de celebración del mundo, cualquiera que sea el motivo y el lugar para su realización. A la rumba salsera, en Cali, se asiste con "la pinta", una indumentaria propicia, informal pero elegante, (de acuerdo con las convenciones que definen la elegancia para un sector social, en determinado momento ) asi sea la única prenda fina que se tiene. Aunque las modas cambian, en las décadas del $40-50$ por ejemplo, los hombres se distinguian por el uso de los zapatos combinados - de dos tonos - como los que tiene Robert de Niro cuando aparece en la película "New York New York" con Liza Minelli. En los 60 - 70, era el uso de "los quesos", zapatos mocasines blancos, preferiblemente sin medias, que para entonces hacian parte del código de la elegancia del rumbero caleño. Esta elegancia informal ha cambiado, sin duda, ante la presencia estandarizada del blujean y los tenis, (entre otras razones,) pero se conserva sobretodo entre veteranos bailadores del ayer que siguen vigentes en bailaderos y viejotecas donde se reencuentran con la salsa y su ambiente, o como lo hemos observado también en los veteranos y elegantes bailadores del danzón en México, o del son y el montuno en las fiestas del come-back en la isla carbeña de Curazao.

Ponerse la "pinta" ( para el rumbero y la rumbera) es una forma especial de prepararse para el baile como un acontecimiento singular, con todo lo que ello implica o presupone : relaciones sociales, amistad, encuentro amoroso, contactos furtivos, enamoramientos fugaces, sensaciones eróticas, energía y vibraciones indescriptibles. Al rito profano del ritmo se asiste por principio, con actitud alegre y extrovertida, con entusiasmo y a veces con algarabía. Por eso bailar es algo más que un código para ejecutar pasos y movimientos. En el caso del rumbero que estamos describiendo la predisposición para ir a bailar integra una actitud subjetiva a una estética, en una práctica social que se opone a la disciplina de la producción económica , a la formalidad del uniforme, $y$ a la indumentaria convencional del trabajo en la calle, en la fábrica o en la oficina.

\section{EL BAILE COMO LENGUAJE : UN OBJETO SEMIÓTICO}

Asumir el baile como un lenguaje implica definir un punto de vista semiótico, para analizarlo, tanto en su especificidad y en comparación con el 
lenguaje verbal, como en sus articulaciones con otros lenguajes no verbales. Implica también comprenderlo como un particular sistema de significación que compromete a los agentes participantes en el baile y en la fiesta. Este conjunto de relaciones configura un campo, de por sí complejo, que nos obliga a establecer algunos procedimientos metodológicos necesarios para los propósitos de esta exposición.

Ahora bien; si se piensa en una posible comparación entre el baile y las lenguas naturales, ella debe relativizarse, porque no parece probable encontrar equivalencias homológicas entre sus unidades. Además, el código del baile es más limitado, como lo son en general los códigos de todos los sistemas no verbales ; las posibilidades de selección y combinación de sus unidades y registros son menores que en el lenguaje verbal. Intentemos un ejercicio imaginario : si pudiéramos juntar y consolidar todos los movimientos, pasos, gestos y ademanes del cuerpo humano, tomados de las distintas danzas folclóricas que hay en el mundo, más los que se han desarrollado a través del ballet, y los que provienen de todos los bailes populares, tendriamos un conjunto riquísimo en expresiones kinésicas y proxémicas. El repertorio sería inmenso pero no ilimitado ; jamás sería infinito, ni semejante al número de palabras y enunciados que se producen con un idioma a lo largo de su historia, ( $\mathrm{y}$ menos aún en todos los idiomas ), ni sería igual a las combinaciones de sonidos que se producen en la música.

\section{El baile de la salsa o la salsa y su baile}

La salsa es una forma abierta para asumir y asimilar diversos géneros de la música popular, bajo una estructura polirrítmica regida por los cinco tiempos de la clave, las descargas de percusión, las improvisaciones instrumentales, el repentismo y los desafios verbales.

La internacionalización de la música salsa en las décadas del 60 y 70, y su mundialización durante los 90 , han expandido la audición y el gusto por ella no sólo entre los latinos regados por el mundo, sino en poblaciones con otras tradiciones culturales y musicales, como sucede actualmente en varios países europeos, africanos, Japón y Brasil. Esa expansión de la salsa ha potenciado su bailabilidad, es decir, ha ampliado sus posibilidades expresivas, en tanto que su baile es igualmente una forma abierta que si bien responde a un código, este es a la vez cerrado y abierto, plástico y flexible, porque lo orientan la síncopa y la clave. Es la bailabilidad de la salsa que tiene en ellas la condición necesaria y suficiente para liberar el cuerpo y su energía; el estímulo vital para ejecutar con libertad, pasos, gestos y coreografias ya aprendidas o improvisadas, porque el bailador improvisa con el cuerpo lo que el músico improvisa con sonidos e instrumentos, y el cantante con versos y pregones. Por eso, el baile de la salsa como lenguaje corporal es un complejo 
de estilos y dialectos, antes que un esquema rígido para moverse musicalmente.

La descripción sincrónica que se intenta a continuación está focalizada en el baile de la música salsa, y más especificamente en el modo de bailar la salsa en la ciudad de Cali, considerándolo como un dialecto especifico de ese lenguaje y no como la única (ni la mejor) forma de bailarla. Aunque sabemos que algunas acciones y movimientos tienen un carácter universal - o tienden a serlo - porque igual se pueden apreciar en el modo de bailar la salsa en otras partes, y porque se encuentran así mismo, en otros bailes populares, o en el baile de otros géneros del folclor urbano.

Vamos a postular cinco criterios generales desde los cuales es posible describir ese lenguaje y los códigos que lo forman. Ellos son: 1- Adoptar la relación de la pareja enlazada como la relación fundamental entre los bailadores. 2- La existencia del código kinésico. 3- La existencia del código proxémico. 4Las partes del cuerpo donde se concentra el énfasis del movimiento dancístico. 5- La correspondencia o sincronía entre los pasos del baile y la estructura rítmica de la canción.

1- Primer criterio: Reconocimiento de la pareja enlazada como el núcleo de la relación fundamental en el acto de bailar. Aunque existe la posibilidad de romper la pareja mediante la presencia de un tercero o también la posibilidad del baile individual, del bailarin solista, o de las coreografias, como sucede en otros bailes (el trance o tecno, el rock, el rap), aquí hemos fijado la atención en el baile de la pareja enlazada. A ella se adscriben los códigos kinésico y proxémico que constituyen el baile propiamente dicho, como el objeto privilegiado de nuestra descripción.

\section{La naturaleza del código: kinesis y proxemia}

Hemos insistido en que el baile es un lenguaje no verbal. Por lo tanto su singularidad hay que buscarla en la naturaleza de los códigos primarios que lo constituyen y que hacen posible la performatividad del cuerpo; esos códigos, que no son escritos sino actuados, son los de la kinesis, (la gestualidad) y la proxemia, (en este caso las distancias corporales involucradas en el acto de bailar, en su significación social ). Los códigos kinésico y proxémico se complementan con un código secundario, el sistema verbal, a través de un repertorio léxico que nombra las acciones del baile : sus pasos, ademanes, estilos y modalidades.

\section{El codigo kinésico}

2- Segundo criterio : Los pasos y los movimientos articulados de la pareja, como unidades significativas. El baile es un juego permanente de articulaciones, ensambles y acoples corporales necesarios para poder 
interactuar. En eso consiste el código. Bien sabemos que la realidad es siempre más compleja que su descripción ; y en este caso los modos de bailar son tan amplios, tan diversos, incluso dentro de un mismo género, que resulta difícil reducirlos a un esquema cerrado. Sin embargo, es posible analizar un sistema básico que tiende a ser constante, independiente de las variaciones. Pero,si se postula la existencia de un código gestual, es necesario definir sus elementos. ¿Cuáles son sus unidades mínimas y cómo se articulan para llegar a ser un eficaz sistema de comunicación corporal - intersubjetiva ? En principio, el adoptar un punto de vista sincrónico nos permite afirmar que el código kinésico está conformado por dos grandes componentes: A- El conjunto de acciones que integran una secuencia lógica previa al baile. B- El repertorio de pasos, gestos y movimientos del cuerpo en un sistema de acoples y sincronizaciones entre la pareja, que configuran el baile en su naturaleza fisica y social.

Si admitimos que el baile es un lenguaje y con él podemos comunicarnos sin necesidad de las palabras, podemos admitir entonces que el baile entre la pareja equivale a un diálogo de los cuerpos que "hablan". Y como en todo diálogo, ( siguiendo el modelo del análisis conversacional ) hay por lo menos un inicio, una tomada de turno, un tópico que cambia y un cierre. En el baile también podemos identificar esta secuencia, si retomamos el conjunto de acciones y el repertorio de pasos que conforman el código, materializado en la performatividad del cuerpo.

\section{De las acciones previas a los pasos bailables}

La primera acción consiste en la invitación a bailar; es la propuesta de un contrato que se acepta o se rechaza. En una sociedad patriarcal como la nuestra, quien toma la iniciativa de la invitación es generalmente el hombre; aunque en circunstancias de familiaridad e informalidad, los roles se pueden invertir. Una mano tendida, un guiño de los ojos, o un gesto ostensivo, son suficientes para marcar esta acción e iniciar el proceso. La invitación a bailar por parte del hombre - ese es uno de sus roles - refleja claramente el androcentrismo predominante en la cultura "occidental". Y continúa a lo largo del baile, pues es el hombre quien lleva la pareja, quien marca el paso que ella debe seguir, para complementarlo. Esta relación es asi y no al revés, aunque no sabemos si es una regla universal, al menos en la cultura occidental. Encontramos en ella una sutil forma de control y dominación convencionalizada por parte del hombre sobre la mujer, (aceptada por ella como parte del juego ) que igual podemos identificar en otros contextos. Hay, en esta primera acción, una analogía con las convenciones establecidas para el matrimonio y para las relaciones sexuales. Tradicionalmente, en la cultura judeo-cristiana y patriarcal, el hombre pide la mano de la mujer para casarse con ella (como lo hace en el baile). Y para el acto sexual, lo normal hasta ahora ha sido que el hombre se lo pida a la mujer, aunque actualmente las cosas están 
cambiando aceleradamente ( para fortuna de los hombres). De todos modos la tendencia dominante sigue siendo la androcéntrica. Un refrán colombiano lo sintetiza magistralmente y vale tanto para el baile como para el amor: "El hombre propone y la mujer dispone".

Si la mujer acepta la invitación a bailar sigue la segunda acción: el acople de las manos. El varón toma con su mano izquierda la mano derecha de la mujer y coloca sobre la cintura, la mano derecha de él, con una ligera presión sobre el talle para indicarle con este gesto, los movimientos a seguir. Ella, por su parte, coloca su mano izquierda en el hombro del hombre, completando así la unidad de esta segunda acción que es también universal para la salsa y el baile de otros géneros en la pareja enlazada.

La tercera acción es el acople de los pies ; la pareja debe sincronizar (en un acto reflejo para los bailadores consumados) la posición de los pies para iniciar el baile. Bailar, en la pareja enlazada, implica un sistema binario de movimientos alternos, complementarios, a tiempo o contratiempo ( se actúa siempre con dos pares : de manos, de piernas y de ojos ). Esta presencia de unidades discretas ( relaciones de oposición ) ocurre tanto en la kinesis como en la proxemia, sin que podamos entrar por ahora a detallarlas en su complejidad. Por lo pronto podemos constatar empíricamente que el baile sigue la marcación de las dos o cuatro pulsaciones por compás ; desde la marcación más elemental hecha con los pies siguiendo el "un, dos - un, dos," hasta la segmentación de los cuatro tiempos, o su subdivisión en unidades menores, con pasos más rápidos, en un procedimiento analógico al que ocurre en la subdivisión de una nota musical. $Y$ es aquí donde se refuerza nuestra idea de que el baile representa el ritmo y no un objeto o una acción externa a él. Ya hemos dicho que si acaso el baile representa algo, ese algo es el tiempo musical, el tiempo rítmico que el oido y el cuerpo recrean mientras dura la canción.

Ahora bien, con respecto a la kinesis, pueden haber varias opciones en los pasos, dependiendo de las células rítmicas; de los compases si son a dos o cuatro tiempos; de las frases o periodos melódicos compuestas en cuatro, ocho o dieciséis compases. Así mismo, con el gesto se puede marcar la sincopa al señalar el tiempo débil del compás con una leve inclinación de una parte del cuerpo hacia la derecha o a la izquierda, con una caída de los hombros, un giro en las caderas o sacando uno de los pies, para sincronizar en el momento justo, el cuerpo, la música y el tiempo.

Empiricamente, al apreciar los registros grabados, se observa que si el hombre sale con el pie derecho hacia atrás, ella lo hará con el pie izquierdo hacia delante, - o visceversa - para ocupar el espacio dejado por él. De aquí en adelante en elaboraciones más complejas, para el caso de la salsa, los pasos se alternarán sucesivamente hasta el momento en que se decide cambiar de movimiento, recordando que el corte y los cambios son generalmente iniciativa del hombre que la mujer debe seguir. Por ejemplo, el 
hombre sostiene a la mujer para que ella dé las vueltas, la suelta o la empuja suavemente para cambiar el ritmo, aunque en situaciones de familiaridad e informalidad, estos roles pueden invertirse parcialmente.

El desconocimiento de la tercera acción puede ser el comienzo de un desencuentro que impide o dificulta la armonía al bailar. Aunque los buenos bailadores suelen superar este impase rápidamente, si es que se presenta, porque lo normal es que se acoplen de manera inmediata y espontánea. Pero en las parejas donde uno de los dos no es un buen bailador, o no sabe bailar salsa, el desencuentro de los pies se percibe claramente desde el inicio. En otras palabras, quien no se acopla en la alternancia de los pies, puede quedar en evidencia como alguien que no sabe bailar. Este hecho tiene fuertes implicaciones simbólicas y sociales alli donde hay una cultura del baile, es decir donde éste está altamente codificado como un lenguaje y donde funciona como un importante escenario de socialización a través del cual se obtienen ciertas gratificaciones, porque del bailar bien se puede derivar una buena amistad, un romance, un intercambio erótico, o incluso una relación sexual. Cuarta acción : el primer paso, propiamente dicho. Este primer paso se repite con algunas variantes menores, mientras dura la introducción de la canción, pero conservando la alternancia de los pies, para no pisarse o no tropezar bruscamente, como sucede usualmente cuando uno de los dos ignora el código. Quinta acción: la secuencia de pasos que van surgiendo programados o espontáneamente. Es el repertorio de gestos que 142 se flexibiliza y se diversifica en un amplio espectro, como puede observarse en el contexto "natural" del baile o más detenidamente en el registro audiovisual del baile de la salsa donde, viéndolo comparativamente, encontramos la mayor variedad de estilos, pasos y figuras. Por eso es tal vez el más rico en expresividad y en posibilidades de comunicación corporal, entre los bailes populares de hoy. El estudio puntual de dicho repertorio, desborda los propósitos de este ensayo ; entonces, hasta aquí llega nuestra descripción. Son los límites reales que el baile como lenguaje impone al análisis racional con el lenguaje verbal. Un impedimento muy dificil de superar... al menos por ahora.

\section{El codigo proxemico: distancias físicas y distancias sociales. La distancia máxima, la distancia mínima y la distancia íntima}

3- Tercer criterio : Una vez definida la pareja enlazada y su kinesis, el criterio siguiente corresponde a la distancia de los cuerpos. Pueden identificarse dos extremos : desde la distancia íntima de dos cuerpos que se pegan literalmente, hasta la distancia máxima determinada por la extensión total del brazo, o la separación y el desprendimiento de la pareja a una distancia mayor. Este conjunto constituye el código próxémico, o sea, la 
regulación y el control del espacio en su dimensión simbólica y su significación social ${ }^{24}$.

Para el caso de la danza y el baile, la distancia y la posición de los cuerpos no ha sido la misma a lo largo de la historia. Asi por ejemplo, en los branles franceses del siglo XVl, el hombre conserva la distancia suficiente para venerar a la mujer y saludarla quitándose el sombrero con gestos de cortesía y caballerosidad. Al bailar, la toma de la mano con dos dedos sólamente o la agarra por el brazo llevándola a su lado en idas y venidas sucesivas, como si estuvieran caminando. Ella, con la cabeza baja, se balancea suavemente mientras desvía su mirada en dirección opuesta al rostro del hombre, pues no puede mirarlo a la cara. Este desvío de la mirada tardará un siglo en modificarse como gesto danzario al lado de otros cambios que se irán dando bajo el reinado de Luis XIV a lo largo del siglo XVII. Bailes como la pavana y el minué (el preferido en la corte del Rey Sol) evolucionan lentamente mientras la real academia de la danza (creada en 1661 ) prescribe los pasos, las coreografias y las buenas maneras dentro de la corte ${ }^{25}$. Aunque se siguen formando hileras frente a frente o una al lado de la otra y se continúa bailando tomados del brazo, ahora las mujeres pueden mirar la cara del hombre y hasta sonreírle, pero conservando las distancias. Cambian las posturas y el agarre por las manos, el vestido se torna más ligero, menos pesado para la mujer a la que ahora pueden vérsele los tobillos. Aparece el corset que aprieta la cintura, y el torso se inclina un poco hacia delante.

Del siglo XVIII al XIX surgen nuevos bailes como la contradanza, el cadril y la polonesa con la que se inician los eventos cortesanos en palacios y castillos, pero aún no se configura el baile de la pareja enlazada. Sólo será en el siglo XIX con el surgimiento del vals, que se define en Europa el formato de la pareja enlazada frente a frente, aunque se siga bailando también hacia los lados y continúen los ademanes de cortesía como una afirmación de los roles masculino y femenino y como una forma de ritualizar las relaciones sociales. La iglesia no tardará en censurar el vals, al considerarlo inmoral porque facilita el acercamiento de hombres y mujeres en público, aunque no se llegue aún a la distancia intima.

Ahora bien; esta breve reseña histórica alude a la danza en Europa de la que se deriva el baile moderno en el paso del siglo XIX al siglo XX. Porque no debe ignorarse que todas las culturas y todas las sociedades han creado sus propias formas de danzar, inicialmente como expresiones rituales con fines religiosos. Sabemos también que en América Latina y el Caribe los pueblos aborigenes danzaban, como en el caso de los tainos y siboneyes que realizaban sus areitos para cantar, comer, beber y bailar colectivamente, al ritmo de los tambores mayohuacán y envueltos en el humo del tabaco, según lo narra el cronista español López de Gomara. También los africanos que vinieron al nuevo mundo trajeron sus bailes y coreografias ${ }^{26}$. 
Como ya lo mencionamos atrás, hacia 1870 surgió la polca lundú y el maxixe como un nuevo estilo danzario que se desarrolló en Río de Janeiro, mientras la milonga y el tango se popularizaban en el Río de la Plata. Entre 1911 y 1913, los tres géneros y sus bailes fueron llevados a París con gran éxito, como espectáculo exótico oriundo de Sudamérica. Es legítimo suponer que a partir de entonces, el formato de la pareja enlazada y su proxemia, incluyendo la distancia intima que se evidenciaba en el tango y el maxixe, se haya impuesto como una nueva forma de relación bailable, difundida públicamente, aunque con las reservas propias de los moralistas de siempre. (Observando diseños, ilustraciones, fotografias y pinturas de finales del siglo XIX y comienzos del siglo XX, el baile del maxixe es igual al baile de la lambada que se impuso como una moda hacia 1990, en el Brasil y otras partes del mundo ). No es extraño entonces que un siglo atrás, el escritor portugués Joao Chagas definiera el maxixe en su libro (De Bond) como "enlace impúdico de dos cuerpos, conjunción indecorosa de los sexos ". (Citado por J. Efege, infra ). Este recuento tiene el propósito de ilustrar el hecho de que el formato de la pareja enlazada frente a frente con la distancia intima es un fenómeno resultante del sincretismo sociocultural entre expresiones europeas y africanas en el nuevo mundo. $Y$ se desarrolló a lo largo del siglo XX, bajo diversas modalidades, en el baile del bolero, del tango, del samba cánción, del son cubano, y de la salsa, entre otros.

\section{La distancia íntima}

La distancia íntima, que es la mínima distancia entre los cuerpos, propicia el enamoramiento, las caricias y los besos, los roces de la piel. Permite sentir los aromas y percibir agudamente hasta las vibraciones de la energia cuando el encuentro es pleno. El contacto cercano crea una atmósfera vital que torna innecesarias las palabras; el lenguaje verbal, es apenas aleatorio, en medio de esa burbuja transparente que envuelve a los bailadores. Un halo de erotismo irradia el entorno inmediato. El mutuo consentimiento facilita los toques, apretones, y acelera el contacto, leve o intenso, de los genitales masculinos y femeninos. Así es el amacise, bailar amacizados, como cuando algunas veces se baila el bolero, se baila la salsa, o como incluso se baila ahora en Colombia el vallenato, (que en cierto modo ha suplido el baile del bolero entre los jóvenes de las nuevas generaciones). Es cuando, como reza el dicho popular :" se baila en una sola baldosa" y "se le saca brillo a la hebilla".

Hoy también existen parejas de baile homosexual, que asisten a lugares públicos. Sitios de "ambiente" donde van a danzar hombres con hombres y mujeres con mujeres. Sabemos que esta es una tendencia de los últimos diez años en una ciudad como Cali, y probablemente de otras ciudades latinoamericanas. Se trata de una nueva costumbre en la transición de un siglo a otro, que parece ser cada vez más fuerte. Sin embargo, la pareja 
heterosexual es el formato que ha predominado históricamente y por eso también es el foco de nuestra descripción aquí. Ahora bien, un análisis comparativo del baile homosexual en sus contextos "naturales", seguramente arrojaria interesantes observaciones, útiles para los estudios de género que hasta ahora parecen haber ignorado la importancia del baile como lugar de intensas relaciones sociales, donde interactúan los hombres con las mujeres $y$ donde se construye también el sentido de lo masculino y lo femenino.

\section{La distancia sexual y el freno de mano}

De otro lado, entre las dos distancias extremas de la pareja se pueden reconocer espacios intermedios que pueden presentar diversos significados y funciones, dependiendo del baile y sus actores, como cuando se realizan las vueltas $\mathrm{y}$ las medias vueltas tomados de una mano, o cuando se alternan los movimientos de acercamiento y distanciamiento fisico entre los bailadores. Pero creo que la distancia más importante es la que marca un límite, una barrera invisible para evitar el contacto indeseado de los sexos. Llamaré a esta frontera, la distancia sexual, por medio de la cual se impide el roce de los genitales entre la pareja, cuando ambos, o uno de los dos, (generalmente la mujer ) no lo desea o en realidad no le interesa. Esta distancia constituye a nuestro juicio una regla universal de la interacción bailable. Mantenerse en el limite y traspasar esa frontera hacen parte del juego, de las motivaciones y el placer de bailar. Aunque este límite puede transgredirse según las circunstancias, mediante una actitud deliberada o agresiva por parte del hombre, pero también por la iniciativa directa de la mujer, o por su aceptación gradual y paulatina, o por el mutuo consentimiento de la pareja sin necesidad de las palabras. El gesto del contacto sexual por medio del baile tiene nombre propio en el argot popular de los caleños: se llama "marcar" o "amacizar" a la pareja, cuando el hombre rodea con sus brazos toda la cintura de la mujer, apretándola, y ella, a su vez, se cuelga del cuello del hombre en actitud cómplice, ambos dispuestos para el goce. Pero así mismo, cuando la mujer no lo quiere asume una actitud defensiva a través de un movimiento elusivo o de un gesto represor para conservar la distancia y mantener el hombre a raya. El movimiento : mediante una contracción de la pelvis y una extensión de los glúteos hacia atrás con el cual puede eludirse el contacto. El gesto : aplicando el "freno de mano" cuando ella coloca su mano izquierda en el pecho de él para detener su acercamiento. La mano de ella que normalmente reposa en el hombro del varón se desliza hacia el torax o se posa firme sobre el antebrazo de él como una frase que sale de la boca. Estos desplazamientos son casi imperceptibles como formas sutiles de comunicación y dispositivos de regulación y control proxémico ejercidos por la mujer, en situaciones críticas de contacto sexual indeseado. 
Sólo nos resta una pregunta : ¿Cómo ocurre esta relación en las parejas de baile homosexual? Cuando bailan hombres con hombres y mujeres con mujeres?. Probablemente deben ser muy distintos los tres casos, aunque nuestras observaciones preliminares in situ revelan con frecuencia la proxemia en las tres distancias, con gestos similares a los de la pareja heterosexual. Será necesario en el futuro hacer más trabajo de campo, entrevistas, descripción etnográfica, para precisar las connotaciones y las relaciones de la pareja enlazada homosexual y sus diferencias - si las hay - con la pareja heterosexual.

4- Cuarto criterio. Las partes del cuerpo que intervienen decisivamente en el baile, o las partes donde recae el énfasis en determinados momentos, o en determinados estilos y modalidades de un mismo género. Sin duda, al bailar se activa todo el cuerpo, todas sus extremidades entran en movimiento. Sin embargo, la observación detallada de estilos y tendencias nos revela el predominio de unas partes del cuerpo sobre otras. Ciertos variaciones en el baile de la salsa, como el caleño por ejemplo, acentúan el movimiento de las piernas, particularmente de las rodillas hacia abajo y la punta de los pies, aunque también, en los últimos años, hemos observado un movimiento de la pelvis hacia la derecha y hacia la izquierda, sin mover el tronco ni los hombros. Esta capacidad de disociación de las partes del cuerpo revela un dominio sobre él, que no todos poseen. ( Según la etnomusicóloga norteamericana 146 Yvonne Daniels, en la literatura anglosajona se denomina : "body part isolation"). El desgonce de la cadera y de la pelvis "aisladas" parece ser un don natural para quienes tienen el privilegio de hacerlo con facilidad, como lo demostraron tantas veces Elvis Presley y Michael Jackson; y es un ejercicio exigente para quienes deben aprenderlo como una técnica corporal. Otros estilos destacan el movimiento de la cintura y las caderas en acciones coordinadas con los brazos y las manos, o de estas directamente con los pies. Según el ritmo de la canción, el gusto y la competencia de la pareja, (o por otras determinaciones ), el énfasis del movimiento puede desplazarse de unas extremidades a otras, o activar simultáneamente varias partes del cuerpo, como en las acrobacias que también están presentes en algunos bailarines sobretodo cuando se presentan shows, concursos o espectáculos. La acrobacia, con vuelos, saltos, volteretas y remolinos con la pareja, ( que viene del circo popular y pasa por el cine), surte sus efectos y suscita admiración por el riesgo que implica y la habilidad que exige, pero a nuestro juicio, es un elemento externo al baile, involucrado tal vez por su tremendismo y espectacularidad, "naturales" en el show businees y la cultura de masa ; y por su grado de dificultad que le permite a quienes lo realizan, diferenciarse de quienes no pueden efectuar tales maromas.

Una vez más, la descripción minuciosa y exhaustiva de esta acentuación de las partes del cuerpo es bastante complicada y desborda nuestras 
posibilidades de análisis, por eso no pretendemos realizarla aquí. Sólo constatamos el hecho como un elemento de esta fenomenologia, ilustrándola con datos empíricos obtenidos de nuestra observación, y recordando que es mucho más interesante y placentero bailar y mirar el baile detenidamente, que intentar describirlo por escrito.

5- El quinto criterio se relaciona con la correspondencia entre los pasos del baile, siguiendo la estructura rítmica de la canción. En la música salsa existe un patrón de composición que fragmenta la unidad sonora en cuatro secciones más o menos constantes, algunas de las cuales pueden repetirse según la duración del disco. Las secciones son: a- La introducción. b- El montuno (cuando después de un giro rítmico entra el estribillo que se alterna con el coro). Esta sección suele repetirse mediante los soneos y pregones del vocalista. c- El mambo: se acalla la voz para dar paso a la intervención de los instrumentos de viento que llevan la melodía a un primer plano, mediante frases de diferentes medidas. En esta sección se destaca el talento de los virtuosos en la improvisación y la creatividad de los músicos. d- El cierre o fin de la canción que se anuncia también rítmica y melódicamente como parte de su estructura. El bailador sabe por intuición práctica cuándo se acerca el fin y se prepara para ello. Hay ciertos pasos con los cuales se termina el baile. Por ejemplo, un giro de ella sin soltarse de él ; una vuelta o una media vuelta de ella que termina con el cuerpo ligeramente apretado y recostado sobre el cuerpo de él.

Entre el montuno y el mambo ( la segunda y la tercera sección ) suelen combinarse las descargas polirritmicas, que estimulan los arrebatos de los bailadores. Es cuando el bailador hace gala de sus habilidades mediante figuras, saltos, vueltas y medias vueltas, giros a la derecha o a la izquierda, soltura y retomada de la pareja, círculos hacia dentro y hacia fuera alternando pares de brazos, movimientos improvisados o registros aprendidos y entrenados previamente para exhibir cada uno por su lado, pero teniendo siempre un punto de encuentro donde ambos coinciden. Entre el montuno y el mambo se activa el mayor repertorio de gestos entre los bailadores, donde puede llegarse al extasis o al climax del baile, si los pasos y el acople se realizan bien.

La interacción sistemática del bailador de salsa con las canciones y su danza ha educado el cuerpo ( la cabeza, el torso, las extremidades) y el oído para ese diálogo que se cumple en tres direcciones simultáneas: el de los bailadores entre si ; y el de cada uno de ellos con el ritmo de la canción, reiterando que la sincronización de los dos actores no significa que ambos realicen los mismos pasos simultáneamente sino que ejecutan movimientos complementarios y articulados. 
Creemos, una vez más a partir de nuestras constantes observaciones empíricas, que el bailar bien la salsa es el resultado de una correspondencia casi simétrica entre los pasos y movimientos del código gestual (kinésico) con las secciones de la canción y la interacción proxémica. El buen bailador, hombre o mujer, es aquel que no sólo posee un amplio repertorio de pasos para acoplarse con la pareja, sino aquel que sabe sincronizar sus movimientos $\mathrm{y}$ articularlos con los de la pareja, y de esta con los segmentos rítmicos y melódicos del disco.

De todas maneras, la existencia de unidades discretas homogenizadas en el baile, y sus relaciones de combinación y articulación, susceptibles de aprendizaje en los códigos proxémico y quinésico, nos inducen a encontrar en ellos, como en todo código, posibilidades y limitaciones para sus usuarios. Como todo lenguaje, el baile también tiene una flexibilidad con límites; porque si bien es un lugar para la improvisación y la variación libre en la ejecución de los pasos, también estos están determinados por el ritmo y la relación con la pareja, configurando siempre un conjunto limitado de expresiones para un evento comunicativo que se regula internamente entre los dos actores.

\section{El lenguage verbal: un código secundario}

Si la kinesis y la proxemia son suficientes para el baile, el lenguaje verbal puede resultar complementario para la comunicación, accesorio en la

148 relación o aleatorio, pero en todo caso desempeñando un papel secundario en la acción, porque no bailamos con las palabras. En ese sentido, su presencia no es pertinente para nuestro análisis. El código verbal está presente en las previsibles frases del enamoramiento y el galanteo entre la pareja, o en los comentarios alusivos a la música y el entorno de la fiesta. Pero sólo nos interesa en la medida en que nombra el baile y sus acciones, a través de un repertorio léxico, es decir una nomenclatura, un conjunto de registros verbales creados para designar la acción o las prácticas que la integran, así como también se nombran los pasos del baile, o los estilos de una época en un lugar determinado. En este caso, esos registros corresponden a las distintas denominaciones con que se conoce el baile en diferentes lugares.

Así, en Cuba y otras islas del Caribe, se le llama "Echar un pie". Esta expresión ha llegado a ser un referente de muchas canciones de la salsa y de la música cubana. (Recuérdense, como ilustración, dos canciones al respecto: "Pa'l veintitrés", del venezolano Ray Perez, una canción-homenaje-invitación a bailar en "El Veintitrés", el popular barrio de Caracas. La otra: "Vamos a echar un pie", del neoyorkino Waine Gorbea, compuesta en honor al baile y hecha, consecuentemente, para bailar).

Los procedimientos metafórico y metonímico del lenguaje (y de toda operación simbólica en la especie humana), por medio de los cuales se designa un objeto con el nombre de otro, o se toma apenas una de sus partes para 
representar al todo, está presente así mismo en otros registros más locales (más colombianos y caleños ) como "mover el esqueleto", "tirar paso", "castigar la baldosa", "azotar la baldosa", o "sacarle brillo a la hebilla". Con todos ellos se designa un elemento o una acción del conjunto, que participa del acto de bailar. Cada una de ellas, enfatiza a su vez en un aspecto (el acercamiento de los cuerpos y el juntar de las cinturas, el contacto con el piso, el movimiento de los pies o el esqueleto). Pero a la vez cada una de ellas es una metáfora verbal del baile. Con ellas se connota en tono jocoso y actitud alegre, el placer asociado y derivado del bailar. De otra parte, con el lenguaje verbal se nombran ciertos pasos que han hecho parte del show del bailarín individual, o de coreografias del espectáculo dancistico. Se pueden identificar entre otros los siguientes : el reloj, el pañuelo, el ocho, la tijereta, la caida de la hoja...

\section{El baile: un lenguage y sus dialectos}

La nomenclatura designa también los estilos (variaciones y transformaciones colectivas) como el baile Casino, de los jóvenes de hoy en la Habana, para danzar la salsa y la timba cubana, por medio de circulos, figuras y vueltas de mano de la pareja. O el Cobao, el modo de bailar salsa los negros de Buenaventura en Cali, con la pareja pegada al cuerpo, lo más cerca posible, haciendo un leve movimiento del torso y las caderas, mientras los pies se mantienen fijos en el piso. Este estilo, se asemeja un poco al "come back" que hemos observado entre los salseros adultos de Curazao, que programan estas fiestas para rememorar bailando la salsa derivada del son y la vieja guardia cubana. En estos dos últimos casos, la cercanía de los cuerpos casi estáticos y la lentitud del movimiento, contrastan con el frenesí, la improvisación y el arrebato visibles en el baile casino y en otros modos de asumir el baile de la misma música, por sectores populares de ciudades como Cali y Barranquilla, entre otros.

El baile o el paso del ganso, un estilo que apareció en los "agua' elulos", fiestas juveniles de los adolescentes caleños, durante la década del 60 , que consistía en el diseño de unos remolinos con las manos despegadas del cuerpo, en los costados, o tirándolas por las espaldas ${ }^{27}$. "El pasito Cañandonga", un estilo de bailar la salsa, particularmente la salsa balada, creado por las nuevas generaciones de bailadores y jóvenes caleños, cuando la salsa balada llegó desde Puerto Rico y se impuso en Cali al promediar la década del 80. En esta ciudad, en la discoteca Cañandonga, propiedad de un reconocido bailarín caleño, se asumió un modo singular de bailar la salsabalada, a través del "paso cañandonga" que consiste en un movimiento sincronizado de la pareja, con ademán suave, abriendo el compás de las piernas, flexionando ligeramente las rodillas, con un vaivén acompasado de las manos enlazadas que se alterna con algunas figuras en círculos o semicírculos, pero sin arrebatos ni descargas, como sí se baila en la salsa dura ${ }^{28}$. 
"El Guateque", ( palabra que en Cuba designa una fiesta campesina), se ha convertido en Cali en la denominación de la salsa "dura" y su baile, para diferenciarla de la salsabalada, que se impuso comercialmente como un nuevo esquema de hacer música tropical bailable. La adopción del término y el cambio de siginificado, parece haberse introducido mediáticamente por un conocido locutor de salsa en la radio y la farándula local. Por su intermedio, la expresión "guateque" terminó designando una variante que se conoce también como salsa "brava", sasonada con descargas de percusión y cascadas de polirrtimia ; salsa plena de pregones y soneos para el lucimiento y la improvisación de los vocalistas ; rica en improvisaciones repentinas de los instrumentistas, que despliegan su creatividad para el deleite y el virtuosismo de los bailadores. "El guateque", como baile, lo han desarrollado en la década de los 90 , jóvenes adolescentes, hombres y mujeres de los barrios pobres de Cali, retomando los pasos y el arrebato ya clásico del bailarin de salsa, pero innovando, incorporando otros gestos como las manos entrelazadas vibrando tensamente, para apoyar los brincos que simultáneamente hacen él y ella. Así mismo, han introducido una nueva relación : el baile entre tres, dos varones con una joven, ( a veces pueden ser más ) pero no todos a la vez. Ellos se turnan para compartir la pareja por momentos dentro del baile de una misma canción. La autoselección de los turnos es decidida por cualquiera ya que esta práctica sólo se realiza entre el grupo familiar o de amigos, donde la mujer puede tomar la iniciativa para 150 invitar a la pista. En determinad .momento de la canción, el primer parejo cede la pareja al otro bailador que espera el turno para entrar en acción generalmente en los cortes, cuando hay cambios de ritmo y de sección dentro del disco - mientras el iniciante se retira, esperando la siguiente oportunidad para entrar. Este modo de compartir la pareja es una costumbre aparecida al finalizar la década de los ochenta y aunque la hemos observado también en el baile del hip hop, carece del asedio sexual a que es sometida la mujer - con su aceptación - por dos o más hombres que la amacizan al mismo tiempo por delante y por detrás, en el baile del rap y del reggae. En el baile a tres de la salsa guateque, lo que prima no es el simulacro del sexo, ni el acoso real, sino el placer del juego, el virtuosismo dancístico y la competencia estrictamente bailable entre los varones frente a la misma pareja. Competencia que a su vez, puede estar ligada (in)directamente a formas o intenciones de seducción, conquista y enamoramiento. En este sentido, puede ser considerado como una disputa amable entre dos varones jóvenes por la mujer acompañante.

$\mathrm{Si}$ admitimos que el baile es un lenguaje, cada estilo es el resultado de un cambio colectivo en el modo de bailar. Si se trata de una transformación individual hablamos de innovación personal ; si la innovación se generaliza, (por medio de la observación directa, por una pedagogía convencional, o por la mediación audiovisual ), hablamos de cambio. Los cambios son el resultado de las innovaciones que se van propagando y determinan estilos dentro del 
baile de un mismo género. En algunos casos esos cambios corresponden al aporte que cada generación introduce en su momento, a la historia del baile popular, como una forma de plasmar su sensibilidad; a través de ello comunica con el cuerpo no sólo su forma de asumir las modificaciones al interior de la música, sino que también expresa un principio de diferenciación frente al modo de bailar de las generaciones anteriores, a las que considera como viejas y pasadas de moda. Sin embargo, como veremos después, la valoración simbólica del baile o de la música es también dinámica y puede variar en el tiempo, bajo determinadas condiciones socioculturales, tal como ha ocurrido con el revival de un modo "clásico", arrebatado, de bailar la salsa en Cali, gracias, entre otros factores, al auge de las viejotecas y al prestigio que ese modo de bailar tiene entre adolescentes y jóvenes de los sectores marginales de la ciudad, mientras que para otros sectores sociales es objeto de estigmatización ${ }^{29}$.

Hay, en este aspecto, un procedimiento simbólico análogo al que encontramos en la historia y las dinámicas de las lenguas naturales, consideradas desde un punto de vista diacrónico. Cambian sus registros, aparecen nuevos dichos y modismos que desplazan a los existentes, se actualizan y se resignifican algunas construcciones linguísticas o se crean otras expresiones acordes con nuevas realidades y nuevas exigencias de la comunicación social.

La sociolingüistica distingue la lengua estándar ( la lengua institucional, de uso oficial, consagrada en la escritura ) de las variantes regionales - dialectos regionales - las jergas, y los dialectos sociales, o sea variaciones linguisticas determinados por la segmentación de los roles sociales, por la división social del trabajo, o por la pertenencia a clases o sectores de clase, en correspondencia con la estratificación de una sociedad dada. Si continuamos esa analogia con el lenguaje verbal, desde la perspectiva de la sociolingüística, que estudia las variaciones dialectales de un idioma, esas transformaciones estilísticas en el modo de bailar la salsa equivalen a los dialectos regionales, o a dialectos sociales del baile, como variaciones de un lenguaje estándar, de un código común. Tales dialectos, con respecto a la salsa, son los que hemos registrado con la cámara de video en nuestro trabajo de campo y corresponden a variaciones en el modo de bailar el mismo género, que aunque compartan ciertos pasos en común, el código en su conjunto se realiza de manera diferente, en La Habana, en Nueva York, en Puerto Rico, en México, en Cali, en Buenaventura, Barranquilla o Curazao. Aunque dentro de un mismo pais, o incluso dentro de una misma ciudad podamos encontrar diversos estilos y variedades dancísticas. (Por otro lado, hemos de reconocer un repertorio (un dialecto? ) gestual que aparece como respuesta kinésica al sonido musical, sin que constituya un baile propiamente dicho. Nos referimos a ciertos gestos miméticos que simulan el toque de los instrumentos (una flauta, una trompeta, un piano, tocados con las manos en el aire ) y a onomatopeyas que imitan sobretodo los instrumentos de percusión. Vocablos como "Ran kan kán, ran 
kan kán", "cucutu prá cu prá" y otros que acompañan el gesto danzario en fiestas y discotecas, hacen parte de un repertorio complementario al baile como un lenguaje no verbal.)

Pero independientemente de los pasos y movimientos comunes o diferentes, lo que comparten como un saber colectivo bajo la forma de un lenguaje corporal, está ligado a un sentimiento profundo por la música y su baile, expresado en el placer, la emoción y la descarga de energía que experimentan los bailadores cuando el ritmo los posee. Este saber colectivo y compartido, vinculado a una memoria musical, es motivo de integración, clave de reconocimiento y signo de identidad, allí donde se vive y se asume de manera auténtica como expresión de una cultura. En este sentido, la puesta en escena de ese lenguaje por los actores "naturales", contrasta notablemente con aquellos sectores de la sociedad, (o con otras sociedades) donde el baile no pasa de ser un ejercicio mecánico, una técnica individual, una moda condenada a desaparecer o un dispositivo meramente convencional de las relaciones sociales.

\section{El baile del danzón}

"Baila asi, baila asi, suave no pierda el compás..." (Miguel Matamoros)

El otro caso que ilustra bien nuestra hipótesis del baile como lenguaje 152 y como metáfora del tiempo, es el baile del danzón tal como ocurre actualmente en la ciudad de México, donde lo hemos podido presenciar y registrar audiovisualmente. Históricamente, el danzón ha estado presente en México a donde llegó desde Cuba por la península de Yucatán y el puerto de Veracruz, desde finales del siglo XIX y comienzos del siglo XX. Luego fue llevado a la capital, donde se arraigó en el célebre Salón México, como parte de una tradición que se ha prolongado en otros salones de baile como el Salón Colonia, Los Angeles y el California, que fueron los lugares observados para este trabajo ${ }^{30}$. Semanalmente concurren allí, en horario vespertino y hasta las once de la noche, cientos de personas mayores de 40 años, hombres y mujeres que se dan cita para escuchar y bailar el danzón interpretado por una orquesta en vivo ( una danzonera) que alterna su participación con una sonora encargada de interpretar los otros ritmos de la vieja guardia cubana, particularmente la guaracha y el mambo que también se bailan, pero de otra manera. La descripción que sigue se circunscribe sólo al danzón y su baile. Para ello hemos contado también con el testimonio del señor Gustavo Sánchez, veterano bailarín, miembro de la academia mexicana del danzón y asiduo visitante del "circuito del dancing", como él mismo lo llama. Según él, "El danzón es un ritmo en compás de $2 / 4$ y consta de varias secciones, tal como se ha desarrollado en México : Una introducción o estribillo, que se repite. Un 
primer trío, de clarinetes ; un segundo trio, de violines; y un tercer trío, de metales (trombones ú otros). Entre cada trío se repite la introducción que se traduce en un "descanso" en el baile : una parada de los bailadores frente a la orquesta para aplaudirla en un gesto de reconocimiento a los músicos...Melódicamente, el danzón incorpora frases y fragmentos de canciones populares o incluso de obras clásicas, como parte de su estructura. Una de las características rítmicas del danzón es la figura del cinquillo (representada por tres corcheas y dos semicorcheas ) que se marca en el baile" ${ }^{\prime \prime 1}$

Para G. Sánchez "El danzón conforma sus pasos básicos de cuatro, ocho y hasta dieciséis compases, con pasos cortos, deslizados y contoneos del cuerpo, ceñidos a un canon, con el cual se baila el danzón en México, diferente a como se baila en Cuba.". Ese canon actuado, de acuerdo con G. Sánchez, se ha reglamentado por escrito y se utiliza en eventos y concursos para decidir y premiar a los mejores bailarines. "Porque se baila siempre con el tiempo del compás, por eso se puede calificar con precisión si un bailarín lo hace bien o no"- Concluye Gustavo Sánchez - Hay aquí una conciencia metacognitiva, que trasciende el mero acto de bailar, para erigirse como un discurso racional investido de poder decisorio. Este fenómeno marca también una diferencia radical frente a otros casos en los que el baile se ejecuta independientemente de un tal discurso racionalizador y normativo. Hemos de suponer que tal canon se codificó mucho tiempo después de que el baile se hubiera desarrollado como un lenguaje, y no al revés.

Ahora bien, teniendo como referencia la pareja enlazada, el canon puede describirse de la siguiente manera a modo de reglas o prescripciones : La primera consiste en dejar pasar los dos primeros compases de la introducción o estribillo que se repite igual. La segunda regla es comenzar a bailar en el primer tiempo del tercer compás. El buen bailador lo hace de manera práctica con precisión sincrónica. Tercera regla: cada paso coreográfico está comprendido en un compás y por lo tanto el paso se cierra (con los pies juntos ) al término (en el último tiempo ) del compás. Los primeros pasos dan lugar a la figura del "cuadro" $(1,2,3,4)$, que como los "paseos", tiene sus variantes: a la derecha, a la izquierda, al frente, en tres cuartos...Cuarta regla : continuar (salir) en el primer tiempo del siguiente compás. Quinta regla : descansar los cuatro compases que dura el estribillo, que se repite, intercalado entre un trío y otro. Sexta regla : cuando suena el montuno la pareja se abre pero no se suelta de las manos. Según G. Sánchez, "No se debe perder el contacto"... "Si se dan vueltas deben mantenerse tomados de la mano y si requiere cambiar de mano puede hacerlo, pero siempre en contacto. Si se sueltan se transgrede el canon..." Observamos en esta prescripción un principio binario de la pareja enlazada cuya relación kinésica y proxémica puede ser cerrada o abierta pero nunca suelta. 
Según el señor Sánchez, "La música también está hecha de silencios, por eso el baile tiene también su tiempo perdido, tiempo para los floreos y la improvisación de los bailarines, pero dentro del canon. Porque hay otra forma de bailar el danzón, que es de show, de teatro y exhibición en el que se hacen hasta maromas, pero ese no es el danzón clásico que hemos descrito".

Ese danzón de show corresponde en nuestros términos a un dialecto, es decir una variante del lenguaje, que por supuesto implica también una variante del canon que no describiremos por ahora.

Ahora bien, probablemente no todos los bailarines se acogen plenamente a las reglas descritas con tanta precisión, aunque en nuestras observaciones in situ la mayoría de los participantes cumplió las prescripciones a cabalidad. Apenas pudimos constatar que unas pocas parejas se soltaron en la sección del montuno, sobre todo para dar una vuelta completa (de 360 grados ) y encontrarse de nuevo frente a frente para reanudar el contacto. Pero independientemente de estas excepciones registradas en nuestra observación participante, es claro para los miembros de la academia del danzón en México ( y al Parecer para la mayoría de los bailadores ) que ese canon regula y define no sólo el buen bailar sino que constituye el baile mismo del danzón como un lenguaje no verbal, según lo hemos definido antes, en función de los cinco criterios establecidos : 1- La pareja enlazada. 2La kinesis ( pasos, gestos y figuras propias de este baile ).3- La proxemia ( una distancia autorregulada por la pareja, entre cerrada y abierta, pero sin soltarse de las manos).4- Las partes del cuerpo donde recae el énfasis del gesto danzario. En el baile del danzón el cuerpo se conserva érguido - y por momentos rígido - aún en medio de los paseos, los floreos, vueltas y figuras, marcadas fundamentalmente con las extremidades, pero sin la intervención enfática de la pelvis, ni las caderas, como sí ocurre en otros bailes.5- La sincronización entre los movimientos, pasos y figuras de la coreografia con el ritmo de la canción y sus secciones. La sincronía es, en los buenos bailarines, perfecta. La marcación exacta de los pasos dentro de los tiempos del compás, los cortes, los silencios y los descansos, como gestos colectivizados nos llevan a pensar que el baile del danzón en México es el más codificado, es decir el más canónico de los bailes populares contemporáneos de América Latina, y en ese sentido es una extraordinaria expresión de la cultura urbana. De ello se deriva también su plasticidad y elegancia como una danza de salón que se ha conservado durante más de un siglo, entre sectores populares y de la clase media de la ciudad de México, que asisten a los salones mencionados luciendo sus mejores prendas. Las damas, elegantes, portan su abanico para refrescarse cuando en medio del baile, se introducen los descansos para saludar a la orquesta. Los hombres en su mayoría con saco y corbata, se destacan también por su "pinta", algunos con zapatos blancos o de dos tonos, como parte de una estética que ya hemos reseñado en el baile de la salsa en Cali, con otra indumentaria. El baile de la salsa y el baile del danzón 
(con más claridad) ilustran así nuestra hipótesis del baile como un lenguaje corporal implicando al mismo tiempo un saber que en su ejecución práctica configura la perfecta metáfora del tiempo.

\section{De la salsa y otros bailes de la musica popular contemporánea: una mirada comparativa}

Se trata ahora de proceder comparativamente desde la observación participante, para ver cómo se diferencian los distintos modos de bailar ya no sólo la salsa y el danzón sino otros géneros como el rock, el rap, la lambada, el bolero, el trance y el pogo (el baile del heavy metal), entre otros. Esta comparación se lleva a cabo teniendo como punto de referencia los códigos kinésico y proxémico como constituyentes universales del baile en todas sus manifestaciones. Aunque no se hará la descripción minuciosa de cada género, si se confrontarán en sus rasgos más visibles y en sus implicaciones simbólicas más significativas ${ }^{32}$.

\section{El rock, el bolero y la lambada}

Empecemos por el rock, que nació del "gesto negro"afroamericano (la expresión es del brasilero Miguel Wisnich ) y se difundió por el mundo estableciendo un patrón de movimiento individualizado en el que cada quien baila como quiere. Comparándolo con el tango, el bolero, la salsa o la lambada, pueden descubrirse algunas diferencias. Tomemos como referencia la lambada que llegó a ser un caso especial, aunque haya desaparecido entre nosotros o se haya reciclado en el meneito, el merengue y el reggae. En corto tiempo, la lambada se constituyó en un fenómeno masivo transnacional, cuando se impuso por la radio y la televisión y fue la moda del verano europeo en 1989 y 1990, sobre todo por la danza voluptuosa que se exhibió al mundo; sin el gesto erótico de la pareja enlazada, la lambada no hubiera sido el fenómeno que fue. En vez de reprimirlo, el gesto fue exacerbado, llevado al limite como se puede apreciar en los bailes y en las películas que la promueven.

Si hay algo que reconocerle a este ritmo brasilero, por lo menos como efecto, es que en su momento logró romper la hegemonía individualista del rock cuyo imperio a lo largo de 30 años estableció un modo dancístico en el que cada quien baila como quiere y a la distancia que desee. El rock es en el baile la expresión suprema del individualismo; del no compromiso con la pareja ni el sometimiento a las reglas fijas para la danza. Su kinesis y su proxemia son otras. El rock es, en el límite, la negación del código y la negación del otro. En otras palabras, es el anticódigo que se reconstruye y se disuelve en cada disco bailado. En este sentido, el rock es un baile postmoderno o la expresión bailable de la postmodernidad. No es por azar que surja y se 
desarrolle con la sociedad postindustrial en los años 60 y se haya desarrollado sin mayores variaciones en su forma de danzar como un baile básicamente individualista.

A diferencia de bailes populares como el tango, el bolero, el danzón o la lambada, que exigen como condición necesaria una pareja y un movimiento sincronizado para danzar, el rock prescinde de ellos. Así, en sentido estricto, no es posible bailar tango, bolero, o lambada sin una pareja y un código de movimientos acoplados.

Más aún, no tiene gracia ni sentido hacerlo, pues prevalece el acercamiento de los cuerpos en busca de la intimidad. Lo que estos bailes acentúan y fortalecen (por lo menos en el acto mismo del bailar) es la relación de pareja, no su disolución. El bailar estos ritmos (y algunos mảs como el vallenato o el merengue) supone un reconocimiento del otro con el que se establece una comunicación no verbal, expresada en la ejecución adecuada de los pasos, en la armonía de movimientos que torna innecesarias las palabras en el ritual del baile y la seducción. Son los cuerpos los que hablan, metiendo pierna con pierna, juntando mano con mano y rodeando la cintura con el brazo. El rock tiene poco que ver con esto. De ahí que el baile de la lambada (y después el hip hop) ha contrarrestado la hegemonía dancística individualista del rock, sin que ello haya significado su desaparición.

Ahora bien, como simulacro y sublimación del acto sexual, ni la lambada ni el reggae son algo nuevo; lo novedoso fue su difusión universal vía satélite;

156 su fijación masiva sincronizada por la industria cultural en diversos paises y contextos; su rápida asimilación por pueblos y culturas con tradiciones musicales y dancísticas distintas. Porque el modo de bailar lambada tiene sus antecedentes en la "ombligada" del lundú afrobrasilero que dio origen al maxixe en Río de Janeiro, en el siglo XIX. La difusión masiva de la lambada a través de la imagen audiovisual influyó en nuestro medio en los modos de bailar el merengue y el reggae, que aparecieron simultáneamente al finalizar la década del 80 . Nuestras observaciones comparadas así lo indican al ver el quiebre de las caderas y la posibilidad de bailar por detrás de la pareja, o de armar tríos de bailarines en los que la mujer queda en medio de dos hombres, uno por delante y otro por detrás. Se trata de una innovación significativa (introducida por la lambada y extendida hoy al hip hop en general) pues ni el bolero, ni el tango, ni la salsa, ( y menos el danzón) admitieron la ruptura de la pareja o el baile por detrás. Siempre fueron danzas cara a cara y cuerpo a cuerpo. Con la lambada y el reggae las relaciones se ampliaron. Ahora es posible romper la armonía de la. pareja para jugar con la ambivalencia de los sexos.

Si el rock implica la disolución de la pareja, la lambada, el reggae y el rap asumen un triple movimiento: la constitución tradicional, su disolución en presencia de un tercero y su recomposición con nuevos integrantes. Para entender este fenómeno, habría que pensar en las representaciones 
contemporáneas de la sexualidad, en los nuevos comportamientos, en la promiscuidad y en los sistemas de actitudes vigentes y emergentes frente al cuerpo y al sexo en la sociedad actual.

Pero, a diferencia de la lambada, otros bailes se han introducido entre los jóvenes, unos por la vía de las minitecas y otros en los conciertos de rock, al lado del merengue y del vallenato que ya se baila en Cali. Si la lambada pasó de moda con la década del 80 , ahora son el rock, el hip hop, el merengue y el Vallenato, los que rivalizan con la salsa. $Y$ el breake dance en menor grado, pues por ser baile callejero de hombres jóvenes marginales, exige ciertos movimientos que no todos están dispuestos a ejecutar, así sea en forma individualizada como en el rock o en coreografías colectivas para el espectáculo musical. En cualquier caso, los que no bailan participan a su manera observando a los bailadores, registrando visualmente la puesta en escena, a veces juzgando el baile de los demás.

\section{El rap, el pogo y el tecno}

Una mirada puntual del baile del rap, nos revela dos tendencias definidas: una, la que corresponde al breaking, practicada por varones jóvenes en la calle, en el duro contacto con el suelo y el cemento, como lo hemos observado en algunas calles de Cali y en el central park de Nueva York. (En este aspecto se asemeja a la milonga, antecesora del tango, que era un baile callejero de hombres solos en el Buenos Aires de fines del siglo XIX; jóvenes del arrabal porteño que exhibían los pasos de una danza urbana, moderna y marginal.). Las rivalidades entre pandillas del South Bronx se trasladaron al baile como una forma de confrontación para dirimir disputas territoriales o conflictos grupales ( batallas conocidas como el UpRock). Este uso particular de un baile callejero propició su desarrollo gestual con pasos como el body popping que consiste en imitar los movimientos hidráulicos de un robot; el electric boggie, por medio del cual se representa un cable de corriente eléctrica para transmitir energía utilizando las muñecas, el cuello, o todo el cuerpo; el turtle, (tortuga) poniendo el cuerpo en posición horizontal desplazándose con las manos ; el windmill ( molino), dando vueltas en el aire; el headspin, giros con la cabeza sobre el piso, mientras se sostiene el cuerpo en posición vertical. Estos pasos y sus variantes estilísticas hacen del breakdance un baile de dificil ejecución, no excento de riesgos y lesiones fisicas. En el breaking, no hay lugar para las galanterías de salón, ni para olfatear las fragancias que disimulan el sudor de los cuerpos que bailan en la pareja enlazada. En el breaking, el sudor se mezcla con el polvo de la calle y la contaminación del entorno. Las acrobacias con los pies, los giros (a manera de tornillo) sobre la cabeza, las vueltas y revueltas en el piso se ejecutan con mucha habilidad y poco escrúpulo. El mugre acumulado se torna visible en el torso desnudo, o hace parte de la indumentaria característica de una estética 
del descuido, que contrasta frontalmente con el cuidado y la elegancia de "la pinta" con que el bailarín de salsa se lanza al ruedo de la rumba caleña, o con la gallardia del pachuco mexicano de antaño o de sus émulos de hoy en la ciudad de Los Angeles, o del bailarín de danzón en México DF.

Como folclor urbano, oriundo de la calle en el gheto negro americano, y reproducido en el gheto negro caleño, el breaking bailado por grupos de muchachos, tiene también un carácter agonístico. Está en juego la rivalidad y el desafio entre los actores. Cada quien sale a exhibir su repertorio y a demostrar su habilidad individualmente, pero sin agredir al otro. A diferencia del pogo, ( el baile del punk) donde se violenta mutuamente la humanidad de los participantes, en el breaking, esa violencia no existe, aunque pueda ocurrir en otros ámbitos. El contacto físico en la danza tiene lugar cuando se forman parejas, tríos, o grupos mayores para diseñar una figura en el piso, una cabriola en el aire o una acrobacia que refleja la destreza, el dominio del cuerpo y la fuerza colectiva de los raperos.

La otra tendencia en el baile del rap y el hip hop es aquella en la cual - la participación de la mujer es decisiva para la simulación del acto sexual que se representa en todas las poses posibles. A diferencia de la mayoría de los bailes populares que no representan nada externo a sí mismos,este baile, al igual que la lambada, es una metáfora del coito en sus manifestaciones más obvias,- lo cual, lo asemeja más a la danza - como lo observamos sistemáticamente en la taberna "Nuestra Herencia" en Cali, entre 1992 -1995.

158 Este sitio fue el primero y ha sido el más importante hasta ahora -aunque ya no existe- en la difusión del reggae, el rap y la cultura hip hop entre los jóvenes negros de Santiago de Cali ${ }^{33}$.

En este baile la mujer adopta las posiciones necesarias, desde las más convencionales hasta las "más atrevidas", para acoplarse con el gesto del varón que la "posee", a veces en compañía de otro, o de varios bailadores que se alternan por delante y por detrás, para arrinconarla contra la pared en una acción que parece más real que simulada. Con frecuencia, se diluye con el gesto danzario la frontera entre la representación y el acto mismo, haciendo más difícil la diferencia entre los dos. Muchos de estos ademanes se extienden también al baile del currulao en salsa, (nombre que propongo aquí provisionalmente ) esa fusión que se está abriendo camino en Cali, como una propuesta vanguardista entre la música negra de la costa pacífica colombiana y la salsa en su mejor expresión.

Ahora bien ; en Cali, el rap y otras expresiones de la cultura hip hop han sido adoptadas por las comunidades negras de barrios marginales, como una manifestación radical para canalizar su protesta, su inconformidad con el orden establecido . Así lo evidencian los centenares de niños que deambulan por las calles de la ciudad o se parquean en las esquinas al lado de los semáforos para cantar y bailar las letras y el ritmo que sale de sus voces hambrientas, con el fin de pedir limosna y tener un medio para sobrevivir en "la selva de cemento". 
Pero entre todos los bailes modernos, hay dos que remiten a universos y prácticas distintas, aparecidos en la década del 90 . Son el trance y el pogo. El trance, ( hacia 1995) adscrito a jóvenes de clases medias y altas que asisten a las discotecas para saltar individualmente, brincar en desorden, subiendo los brazos alternadamente, o formando círculos espontáneos que se hacen y se deshacen con la misma rapidez. Cuando hay amistades de por medio, el círculo se cierra con los brazos entrelazados sobre los hombros del compañero, mientras todos saltan simultáneamente, a tiempo que giran en un movimiento de traslación y cortos desplazamientos por la pista. Acompañados con silbatos que intensifican el ruido repiten aceleradamente una frase melódica en un compás (que aproximada y onomatopéyicamente dice así: "pahparará parará papá ") y por frases verbales que se cantan en coro aludiendo al sexo y al consumo de drogas. Aquí no hay pareja enlazada ; la tendencia es otra, más individualista, como en el rock, donde la "pareja", puede ser fugazmente un hombre o una mujer, que se cruza en el zigzagueo del otro. Ni la música ni la coreografia o el salto individual, permiten la sincronización de la pareja enlazada, tal como la hemos visto en el bolero, en el tango, el merengue, la lambada, o en la salsa.

La otra expresión que nos ha llamado poderosamente la atención por su forma de ser y por tener cada vez más adeptos entre grupos de jóvenes, especialmente hombres, es el "pogo", que hemos observado en algunas tabernas o en conciertos de rock en otros escenarios, como el teatro al aire libre Los cristales, en Cali.

Si el bolero provoca la intimidad, si la lambada exacerba el gesto erótico y la salsa el arrebato frenético, y el tango hace gala de elegancia y cadencia sensual, el "pogo", para los jóvenes que lo practican, es ya no solo la expresión del individualismo, sino la representación danzada de la agresividad y la violencia. Es lo que se puede apreciar en una sesión de pogo donde los muchachos, al ritmo del punk se lanzan unos contra otros, se atropellan, se empujan y se dan fuertes patadas como si estuvieran peleando. Tales ademanes los encontramos en idénticas condiciones, pero en otro contexto, en las barras bravas del fútbol. En las tribunas del estadio se reproducen y multiplican por la amplitud del espacio ocupado por miles de hinchas fanáticos, muchos de los cuales son "punkeros". Hasta donde sabemos, este modo de bailar no tiene antecedentes en la historia del baile popular moderno ; tampoco sabemos exactamente de dónde proviene, ( al parecer de la cultura pop anglosajona y llega por la vía de la TV), pero sí constituye una forma extraña de asumir la danza, en la que si acaso hay un reconocimiento del otro es para agredirlo fisicamente, para desa fiar los límites de la tolerancia y poner a prueba su capacidad de aguante. En fin, el pogo parece tener el sentido de una provocación que al final puede derivar en gresca, en la aceptación pasiva de la agresión o en la indiferencia que deviene con el final de cada pogueo. 
De otro lado, puede verse en el pogo una nueva forma de expresión de las rivalidades entre varones jóvenes, en una sociedad de tradición patriarcal, competitiva e individualista como la occidental. Sólo que esa rivalidad ya no se manifiesta con palabras o mediante desafios verbales como en otras tradiciones musicales (la trova y la piqueria colombiana, el joropo colombovenezolano, el soneo cubano, el partido alto brasilero). Tampoco corresponde a las peleas callejeras, donde los jóvenes confrontan sus tensiones en una esquina cualquiera. En el pogo sobran las palabras; el desafio está implícito y solo basta estar presente para aceptar ser parte del "juego". El carácter agonístico se expresa de una manera peculiar : por medio de empujones, codazos y patadas, el más fuerte ejerce su poder y construye su prestigio.

De cualquier manera, es probable que el pogo, como "baile", en tanto fenómeno urbano, inédito hasta ahora, tiene mucho que ver con la violencia característica de la vida moderna y de la nación colombiana, ( y al parecer en otras partes del mundo ) que ya no sólo se representa en la pantalla o se vive en las calles, sino que está presente en un escenario que como el baile fue siempre para el placer, el regocijo o el amor.

\section{"Aquí el que baila gana..."}

"Bailen que aqui el que baila gana" (Orquesta Los Van Van, de Cuba)

Hemos analizado el baile como un sistema de comunicación no verbal, objeto de innovación y cambio por parte de los agentes sociales. Como un lenguaje del cuerpo que tiene sus propios códigos y dialectos; como un escenario de placer donde el amor, el erotismo y la sexualidad también se manifiestan.

Hemos intentado una comparación entre diversos bailes populares del folclor urbano y el cancionero comercial moderno, reconociendo el tránsito de muchos pasos, movimientos y coreografías que circulan por diversos espacios, desplazándose por la calle, el circo popular, el cine, las pistas de baile, y en la última década , transitando por las tribunas populares del estadio, el spa y el video clip, como escenarios de modelación del cuerpo bailador, de un cuerpo históricamente modelado para el goce, a través del baile, en una ciudad como Cali. El baile no ha sido objeto de estudio académico, pero si ha sido objeto de una pedagogía escolarizada, en las academias populares donde lo enseñan, y de una pedagogía informal, en las calles donde se practica, o gracias a la mediación audiovisual del cine y la televisión. Pero este tema será materia de otro ensayo.

Sabemos con certeza que el goce y el placer no son exclusivos del baile de la salsa, pero sin duda ella ha ocupado en Cali un lugar importantísimo en el uso del tiempo libre y la recreación de amplias capas de población 
adscritas especialmente a sectores marginales urbanos, obreros industriales, empleados y funcionarios de clase media. $\mathrm{Y}$ sigue siendo un espacio fundamental de socialización, sobretodo para los sectores mencionados, que son las mayorías en nuestra sociedad, así como ha sido especialmente significativa para la población negra, generalmente pobre, a la que se le reconocen sus habilidades para la música y el baile en esta ciudad. Esta perspectiva étnica y social debe destacarse como un hecho irrefutable en la historia de la salsa en Santiago de Cali, y de ella nos hemos ocupado en otro texto ya citado atrás. Parece claro también que frente a otros estilos y modos de bailar la salsa, guiados más por la polirritmia de los tambores, como sucede en Cuba, en Cali el baile de la salsa se rige por la melodía que facilita la relación de la pareja enlazada y sus interacciones complementarias. Este predominio de la melodía obedece tal vez, al hecho de que los tambores no han hecho parte de una tradición secular, compleja e intensa, como sí ha existido en las islas del Caribe, o en el Brasil, donde se han desarrollado en ricas y diversas manifestaciones ritmicas y dancísticas.

Aun así, en tanto práctica social, recreativa y lúdica, el baile en Cali es una clave de reconocimiento e identidad de los sectores populares urbanos que son los que más y mejor bailan, haciendo gala de un saber compartido. Pero este saber pleno es todavía patrimonio de la gente para la cual, bailar salsa es una vivencia anhelada y no una moda ; para aquellos, cuya cotidianidad está atravesada por esta música y su baile como elementos necesarios a un estilo de vida en el que se resaltan también otras dimensiones de la existencia humana. $\left({ }^{34}\right)$ Porque hay estratos sociales a los que la salsa ha permeado pero la viven de manera artificial o sin mayores compromisos, $\sin$ que ella tenga el valor y la significación que para otros actores ha llegado a tener en nuestra ciudad, o en otras ciudades del país y del continente.

Es aquí donde el baile, además de ser un ejercicio físico, recreativo y placentero, adquiere un valor simbólico diferenciado para este sector de la cultura popular caleña. El estatuto de prestigio conforma una escala de valores que hay que ganar para no quedarse atrás. Por eso la necesidad de aprender a bailar desde la más temprana edad, ( es común que se aprenda a bailar antes que a leer y escribir), porque en la adolescencia aparece el imperativo de tener que bailar bien, como una puerta de entrada segura a la conquista amorosa y al reconocimiento social, o para el lucimiento y la distinción dentro del grupo de iguales. Por eso el baile de la salsa es parte esencial en la construcción de una identidad y en la afirmación de una subcultura urbana. $Y$ los rumberos caleños lo han aprendido sin necesidad de tomar las clases del "profesor" Arthur Murray que según la R.C.A Víctor "Es el mejor y más conocido profesor de baile (porque) cada semana más de 100.000 personas toman lecciones en sus estudios a través del mundo. En T.V. ha sido conocido por $\mathbf{4 0}$ millones de personas; otros millones han aprendido a bailar por correo (ii qué tal !!) o por su libro "Cómo ser un buen 
bailarín". Nunca hemos visto al profesor Murray en Cali, ni en T.V., ni en persona, ni leído su libro, ni sus lecciones por correo. En Cali se baila sin necesidad de acudir a tales artificios tan propios de "los gringos" que todos los días se inventan fórmulas hasta para hacer el amor, como si el amor y el baile no nacieran de lo más profundo y no vinieran desde adentro y no estuvieran unidos por el mismo ritmo vital que los çonvierte en lenguaje $\mathrm{e}^{35}$.

\section{BIBLIOGRAFÍA}

ANDRADE, Mario de. Diccionario Musical Brasileiro. Ministerio da Cultura, Editora da Universidade de Sao Paulo, Sao Paulo, 1989.

ECO, Humberto. Tratado de Semiótica general. Editorial Nueva Imagen, México 1978.

ALÉN R., Olavo. De lo Afrocubano a la Salsa. Géneros musicales de Cuba. Editorial Cubanacán. San Juan Puerto Rico, 1992.

ARGELIERS, León. Un marco de referencia para el estudio del folclor musical en El Caribe. Centro de investigación y desarrollo de la música Cubana- CIDMUC - Seminario del son. Santiago de Cuba, 1982.

DALLAL, Alberto. El "Dancing" Mexicano. Editorial Oasis, México, 1982.

162 ECO, Humberto. Tratado de Semiótica General. Editoral Nueva Imagen, México, 1978.

EFEGÊ, Jota. Maxixe - a danca excomungada. Coleção temas brasileiros. Rio de Janeiro, 1974.

HALL, Edward T. A dimensao oculta. Relógio D'“Ägua Editores-Lisboa, 1986.

HUTCHISON, Ann. Labanotation. The system of analyzing and recording Movement. Theatre Art Books, New YorK, 1973.

MAX, Caicedo H. Introducción a la Sociolingüística. Ediciones Universidad del Valle-Cali 1991.

MARCHUSCHI, Luis A. Análise da conversacao Editora Atica, Sao Paulo, 1986.

MORALES, Abadía G. Compendio general de folklore colombiano.

Biblioteca Banco Popular, Bogotá, 1983. (4a. Edición revisada y acotada) NOVERRE, J. Jorge . Cartas sobre la danza y sobre los ballets. Ediciones Centurión Buenos aires, 1946.

ONG, Walter. Oralidad y escritura. Tecnologías de la palabra. Fondo de Cultura económica - Bogotá, 1994.

ORTIZ, Fernando. Los bailes y el teatro de los negros en el folklore de Cuba. Editorial Letras cubanas - Ciudad de la Habana, 1981. 
RAMOS, Tinhorão J. Pequena historia da música popular-Da modinha ao Tropicalismo. Art Editora: Sao Paulo, 1986.

SALAZAR, Adolfo. La Danza y el Ballet. Introducción al conocimiento de la danza de arte y del ballet. Fondo de Cultura Económica México, 1949.

ULLOA, Alejandro. "Modernidad y música popular en América Latina. En: Iztapalapa, Revista de Ciencias Sociales y Humanidades, Año 11 número 24. México: Universidad Autónoma Metropolitana,1991.

ULLOA, Alejandro. La salsa en Cali - Centro Editorial Universidad del Valle. Cali, 1992.

. Juventud, musica pop y modernidad.Culturas urbanas e identidades sociales. Informe de investigación-Escuela de Comunicación Social, Universidad del Valle-Cali, 1995.

Pagode A festa do samba no Río de Janeiro e nas Américas. Multimais Editorial - Río de Janeiro, 1998.

VERÓN, Eliseo. Lenguaje y Comunicación social. Ediciones Nueva Visión Buenos Aires, 1976.

WAXER Lise A. Cali Pachanguero : a social history of salsa in a Colombian City. Thesis, P.hd - University of Illinois at Urbana Champaign, Urbana lllinois 1998.

\section{NOTAS}

' $\Lambda$ demás de un archivo fotográfico, contamos con registros audiovisuales hechos en la ciudad de Nueva York, durante el concierto del timbalero Orlando Marin y su orquesta, en la plaza de las torres gemelas, cn julio del año 2000, donde concurrieron decenas de bailarines espontáneos, de diversas nacionalidades. Así mismo, tencmos imágenes del baile tomadas en el festival de salsa, celebrado en la isla caribeña de Curazao en agosto del 2000, simultáncamente con cl congreso Bacardi de la salsa en el que participaron bailarines provenientes de Los Angeles, Puerto Rico y Cuba, entre otros. En Santiago de Cali, hemos grabado cl baile de salsa protagonizado por adolescentes, hombres y mujeres, en las audiciones callejeras programadas por jóvenes de los barrios Sicte de Agosto y El Poblado dos, en el distrito de $\Lambda$ guablanca, suburbio marginal de la ciudad. Igualmente, hemos grabado en cl parque de la música, en Cali Colombia, durante las audiciones públicas de salsa, programadas por la asociación de coleccionistas y el encuentro de salsotecas. Registramos cl concurso de bailarines de salsa realizado en la feria de Cali, (diciembre 2000), en el que participaron varias generaciones, desde niños de cinco años hasta veteranos bailadores de la terecra edad, la mayoría de ellos provenientes de los estratos sociales más pobres de Santiago de Cali. Como complemeto, para cstablecer comparaciones e identificar relaciones y diferencias, se tendrán en cuenta otras 
imágenes grabadas sobre el rap y el break dance bailado por raperos del South Bronx, en el Central Park de New York (julio 2000) ; y por raperos del distrito de aguablanca en Santiago de Cali, rapeando y bailando en sus barrios, durante la década de los 90. Igualmente se tendrán en consideración grabaciones del pogo, el baile del heavy metal ejecutado por jóvenes varones durante un concierto de grupos de rock en el teatro al aire libre Los Cristales de Cali, en 1994. De otro lado, contamos con imágenes audiovisuales del baile de samba registradas en la escuela de la Mangueira en el mismo barrio, en Río de Janeiro, así como de la escuela Imperio Serrano, en su actuación en la universidad estadual de la misma ciudad, durante el primer encuentro de investigadores de música popular brasilera, en el que participó también el artista Antono Nóbrega 'presentando diversos bailes del Brasil. (Octubre 2001 ). En el año 2002 hemos registrado las coreografías montadas por el instituto colombiano de ballet INCOLBALLET, dirigido por Gloria castro en su investigación sobre la historia de la danza. ( Cali, enero 2002 ). Y en México grabamos el baile del danzón, en el salón California, donde asisten veteranos y elegantes bailarines que mantienen viva la tradición urbana del baile del danzón (Abril 12/2002). Quiero agradecer a mi amiga Ieteke Witeven en Curazao sus agudas y oportunas observaciones sobre el manuscrito original de este ensayo.

${ }^{2}$ Ann Hutchinson : Labanotation. The System of analyzing and recording Movement - Theatre Art Books, New York, $2^{\text {a }}$.reimpresión, 1973. Págs. 1-2.

${ }^{3}$ Alberto Dallal : El "Dancing" Mexicano. Editorial Oasis-Primera edición 1982, págs. 17,18.

${ }^{4}$. Adolfo Salazar : La danza y el ballet. Introducción al conocimiento de la danza de arte y del ballet. Fondo de Cultura Económica, México 1949. Nota personal del autor, a modo de introducción.

${ }^{5}$ El baile es un saber, pero un saber del cuerpo; y es más valioso en tanto se opone a la disciplina del trabajo. El capitalismo ha domesticado el cuerpo, le ha impuesto una rigidez en aras del rendimiento económico. De ahí que su valor sea doble. Como escenario de placer y como estatuto de prestigio, el baile para los sectores populares en Santiago de Cali, es al mismo tiempo un saber y un poder.

${ }^{6}$ NOVERRE, J.Jorge. Cartas sobre la danza y sobre los ballets. Ediciones Centurión, Buenos Aires, 1946.

${ }^{7}$ A. Salazar. Op.cit. pág 16.

${ }^{8}$ A nivel ontogenético, las onomatopeyas testimonian el principio de la imitación y la semejanza en el origen del lenguaje, pues aparecen en todas las lenguas como articulaciones sonoras que semejan, simulan e imitan los sonidos naturales o los ruidos del ambiente.

${ }^{9}$ Semiólogos como Eliseo Verón y Humberto Eco se han referido a los grados de semejanza e imitación que caracterizan el signo icónico. Así, entre más se parezca una imagen a su objeto (como en el dibujo o en la fotografía) se dirá que el signo ( la imagen ) es motivado, es decir más analógico y más metafórico, por lo tanto, menos arbitrario. Entre menos se asemeje el signo a su objeto, se dirá que es más arbitrario, es decir menos motivado, menos analógico y más metonímico. Pero según U. Eco, entre el objeto y su representación icónica se interpone un código de reconocimiento, que corresponde a un modo de percepción culturalmente 
establecido sobre el mismo. Entonces, la semejanza no se da entre cl objcto y su imagen sino entre ésta y el código de percepción del objeto. Para E. Verón, los grados de mayor o menor semejanza determinan la existencia de lo analógico y lo digital como códigos semióticos equivalentes a la metáfora y la metonimia. Lo analógico como un continuoum ; lo digital, como algo que sc intcrumpe cn su continuidad. Debe advertirse que no todos los autores que se ocupan del asunto comparten la misma terminología. Ver: U. Eco, Tratado de semiótica general

- Crítica del iconismo. Págs. 325-360. E. Verón : Lenguaje y comunicación social. Págs. 95 - 105.

${ }^{10} \mathrm{~J}$. Noverre: Op.cit págs $60,61,68$.

"Sobre el caso cubano véasc Olavo Alén: De lo $\Lambda$ frocubano a la Salsa. Edit. Cubanacán, San Juan Pucrto Rico 1992 pág. 67. Para cl caso del Mapalć cn Colombia leásc la obra de Guillermo $A$ badia Morales: Compendio general de Folklore colombiano Biblioteca Banco Popular, Bogotá 1983 (Cuarta cdición, Revisada y acotada) Pág. 205. Sobre cl Lundú y la danza de "umbigada" en el Brasil véasc Mario de $\Lambda$ ndradc : Diccionario Musical Brasileiro, Universidade de Sao Paulo 1989, págs. 291 a 294. Y: Ramos Tinhorao : Pequena historia da música popular (brasilcra). Art cditora, Sao Paulo 1986 (5". Edicao, revista c aumentada) págs. 251 a 256 -Traducción personal. Sobre la Lambada véase A. Ulloa : Pagode a festa do samba no Río de Janciro... Edit. Multimais, Rio de Janciro 1998, págs. 207 a 210 ).

${ }^{12}$ Muniz Sodré : Samba o dono do corpo. Editora Codecri - Río de Janeiro 1979. Págs. 17, 24.

${ }^{13}$ O.Alén. Op. cit Pág.98.

${ }^{14} \mathrm{R}$. Tinhorao Op. Cit. Pág.59.

is J. Noverre. Op. Cit Pág.39 ^. Salazar Op. Cit págs. 128 a 130.

"Retomando la terminología semiótica de U. Eco y E. Verón, diriamos que el carácter artístico de la danza y cl ballet está determinado no por su relación metafórica (o analógica) con el orden natural, sino por su relación metonímica (o digital).

${ }^{17}$ Yvonne Daniels me ha hecho caer cn cuenta en la existencia de una creciente bibliografia sobre el baile, producida en los últimos años. Lamento no conoccrla toda. ${ }^{18}$ Sobre el tango y su origen sociomusical, véase : Jorge Rivera, La historia del tango. Historias paralelas. Ediciones Corregidor, Bucnos Aires 1977. También, Blas Matamoros: Origenes musicales del tango.Las raíces negras, en Historia del tango, tomo l- Ediciones Corregidor, Bucnos Aires 1977. Y, León Benarós: El tango, los lugares y las casas de baile, en Historia del tango tomo 2-Ediciones Corregidor, Buenos Aires 1977. Ver O. Alén : De lo Afrocubano a la Salsa - Géncros musicales de Cuba 1992.

"Empleamos la noción de "Cancionero" en el sentido que propone el musicólogo cubano Argeliers León (quien la retoma a su vez del folclorista argentino Carlos Vega) en su texto: "Un marco de referencia para el cstudio del folclor musical en el Caribe"Centro de investigación y desarrollo de la música cubana CIDMUC. Scminario del son, Santiago de Cuba, 1982. Esa noción de "Cancionero" es diferente a la de "Complejo genérico", que plantea Olavo Alén ( y que está presente en el mencionado texto de A. León ) para caracterizar "Cinco grandes agrupaciones de géneros musicales de la música cubana..." Scgún Alén : "Estos complejos integran varios géneros afines y dentro de cada uno de ellos se nota cierta homogeneidad en los comportamientos y 
actitudes musicales ...cierta semejanza estilística...y cierto parecido en la aparición de instrumentos y de agrupaciones musicales para su interpretación."Así, el son, el montuno, el guateque, el changüí y el sucu-sucu, constituyen el complejo del son. El complejo de la rumba lo conforman el guaguancó, el yambú y la columbia. El complejo del danzón lo integran los géneros derivados de la contradanza francesa, a saber : la danza cubana, el danzón, el danzonete, el chachachá y la pachanga. Ver O. Alén: De lo Afrocubano a la Salsa - Género musicales de Cuba, 1992.

${ }^{20} \mathrm{La}$ fundamentación histórica de esta categoría (afrolatinoamericaribeño) está desarrollada en mi libro: Pagode, a festa do samba no Río de Janeiro e nas Américas - Multimais editorial, Río de Janeiro 1998.

${ }^{21}$ Sobre la salsa y su origen en el barrio latino de Nueva York, ver César Miguel Rondón : El libro de la salsa-Editorial Arte, Caracas 1980. Sobre el reggae y su origen en barrios marginales de Kingston, véase el texto de Sergio Santana Archbold: Peter Tosh el ministro del reggae. Ediciones Salsa y Cultura, Medellín 1994 ${ }^{22}$ Ver Umberto Eco : Tratado de semiótica general . Editorial Nueva Imagen, México 1978 - Pág. 295.

${ }^{23}$ U. Eco Op. Cit. Pág. 298.

${ }^{24} \mathrm{Para}$ entender la naturaleza y la importancia de la proxemia en las relaciones sociales, véase el libro "La dimensión oculta" de Edward T. Hall , en especial el capítulo sobre "Las distancias en el ser humano". Aunque no menciona el baile, el análisis propuesto por E. Hall es pertinente y útil para nuestra reflexión.

${ }^{25} \mathrm{Se}$ destacan las cinco posiciones de los pies sobre el suelo seleccionadas como fundamentos de la danza y a partir de las cuales se derivan diferentes combinaciones, que han hecho de ella un arte escénico. Ver : A. Salazar, Op. cit págs. 128 a 130. Sobre los areítos en el Caribe, ver Fernando Ortiz : La música afrocubana - Ediciones Júcar, Madrid 1974 Págs. 40 a 139.

${ }^{26} \mathrm{La}$ bibliografia al respecto es amplia. Desde los estudios pioneros de Arthur Ramos sobre "El folclor negro del Brasil" y Mario de Andrade, hasta las investigaciones de José Ramos Tinhorão, y Muniz Sodré, entre otros, sobre el samba y la música popular brasilera. Sobre el baile del maxixe véase: Jota Efegé, Maxixe a danca excomungada. Colecao Temas brasileiros - Río de Janeiro 1974. José R. Tinhorao: Pequena historia da música popular brasileira. Art editora, Sao Paulo 1986.

${ }^{27}$ Sobre las fiestas y bailes populares en Cali, puede consultarse A. Ulloa : La salsa en Cali. Centro editorial Universidad del Valle, Cali 1992 (2a. Edición). ${ }^{28} \mathrm{EI}$ nombre del "pasito cañandonga", se debe al lugar donde se impuso este modo de bailar en la ciudad : en la Discoteca Cañandonga, reconocida como uno de los más importantes bailaderos de salsa en aquella época en Cali, justo cuando el apogeo del narcotráfico y su bonanza económica fomentaron el surgimiento de grupos musicales dedicados a la interpretación de esta música en clubes, bailaderos y discotecas. No sería aventurado afirmar que "el pasito cañandonga" es otra de las manifestaciones simbólicas que lleva la impronta del narcotráfico en Cali, durante los últimos años, como expresión no sólo de una época o de una moda, sino de una sensibilidad y un modo de ser que prevaleció como el modelo a seguir en el contexto de la rumba salsera caleña.

${ }^{29}$ Sobre "el guateque" en Cali y el fenómeno de las viejotecas, puede consultarse el trabajo de Lise A. Waxer. Cali pachanguero: A social history of salsa in a colombian city. Thesis doctoral. University of Illinois at Urbana - Champain, 1998. Págs. 186 y 247. 
${ }^{30}$ Una referencia al danzón y estos salones de baile puede lecrse en el mencionado libro de A. Dallal : El "Dancing" Mexicano, particularmente el capítulo Ill. Para una mirada del danzón y los Salones de baile, analizados desde una perspectiva más antropológica, véase el artículo de Amparo Sevilla, "Los salones de baile: espacios de ritualización urbana". En : Néstor García Canclini (Coordinador) Cultura y Comunicación en la ciudad de México. Grijalbo/ UAM México 1998. ${ }^{31}$ Este testimonio y los que siguen fueron dados por el señor Gustavo Sánchez Vásquez del Mercado, en entrevista concedida al autor, el 12 de abril de 2002, en la ciudad de México, durante nuestra participación en cl IV congreso de la A sociación Internacional de estudios de la Música popular, rama latinoamericana IASPM-LA en el que presentamos nuestra ponencia sobre el baile.

${ }^{32}$ Las primeras formulaciones al respecto, pero sin considerar explicitamente los códigos kinésico y proxémico, están en mi articulo "Modernidad y música popular en América Latina", publicado en :Iztapalapa, Revista de Ciencias sociales y Humanidades. Año 11, Número 24. Universidad Autónoma Metropolitana, México 1991.

"Una referencia sobre la adopción del Reggae, la idcología rasta y el rap cn Cali, puede encontrarse en mi trabajo "Juventud, música pop y modernidad. Culturas urbanas e identidades sociales". Informe de investigación, Escucla de Comunicación Social, Universidad del Valle - Cali 1995.

${ }^{34}$ El prestigio y el poder que se derivan del bailar bien, hacen parte de la distinción simbólica en diferentes culturas a lo largo de la historia de la humanidad. Cito dos casos ilustrativos: primero, $\mathrm{cl}$ de los indigenas Tainos y Siboneyes del Caribe, descritos por el cronista español López de Gomara : "En los areitos (las ficstas rituales), los indios comen y beben hasta emborrachar. Quicn más bebe cs más valiente y más honrrado... bailan seis horas sin descansar...y el arcito a veces les dura desde un dia hasta otro...El que más baila es más estimado." Citado por Fernando Ortiz en : La música afrocubana, cdiciones Júcar, Madrid 1975, pág. 90. El segundo caso es citado por Walter Ong en su obra Oralidad y Escritura : "Al pedirle su opinión acerca de un nuevo director de la escuela de la aldea, un africano contestó al investigador J. Carrington :- Veamos un poco cómo baila"(Fondo de Cultura Económica - Bogotá 1994 - pág.60).

${ }^{35}$ El dato es tomado del disco L.P Arthur Murray"s

- Música para bailar

- Pachangas. RCA Victor, New York. L.P hecho en Venezucla ( sin fecha de producción ) 
168

\section{Palavras-chave}

1. Lenguaje no verbal

2. Semiótica

3. Kinesis

4. Proxemia

5. Pareja enlazada

6. Salsa

7. Mimesis 